\title{
THE LODE-PORPHYRY MODEL AS DEDUCED FROM THE CUMARU MESOTHERMAL GRANITOID-HOSTED GOLD DEPOSIT, SOUTHERN PARA, BRAZIL
}

\author{
MÁRCIO D. SANTOS*, OTHON H. LEONARDOS**, ROBERT P. FOSTER**** \& ANTHONY E. FALLICK****
}

\begin{abstract}
RESUMO O MODELO LODE PORFIRÍTICO DEDUZIDO A PARTIR DO DEPÓSITO MESOTERMAL DE OURO EM GRANITÓIDE DO CUMARU, SUL DO PARÁ BRASIL Um novo tipo de depósito aurífero foi descrito para o Craton Amazônico, nos greenstone belts da Província Carajás. Em vez de veios mesotermais, hospedados em milonitos, ou depósitos exalativos, já reconhecidos na Província Carajás, o depósito auríferó do Cumaru é hospedado em um pluton granodiorítico cálcio-alcalino arqueano, típico de arcos vulcânicos. O Granodiorito Cumaru colocou-se em domínios transtensivos de uma zona de cisalhamento tipo rabo de cavalo, cortando rochas vulcano-sedimentares miloníticas do greenstone belt arqueano de Gradaús. Os veios de quartzo auríferos do Cumaru ocorrem em fraturas com direção preferencial $\mathrm{NE} / \mathrm{SW}$, na borda NW do pluton do Cumaru, envolvidos por um enxame de filonetes em padrão stockwork, com mineralização disseminada em uma matriz de alteração fflica. Três tipos de fluidos foram identificados nos veios de quartzo do Cumaru. Fluidos aquo-carbônicos, imiscíveis no momento de seu aprisionamento, foram interpretados como fluidos metamórficos relacionados à zona de cisalhamento. O segundo tipo de fluido é representado por inclusões de salmouras do sistema $\mathrm{H}_{2} \mathrm{O}-\mathrm{NaCl}-\mathrm{KCl}-\mathrm{CaCl}_{2}$, interpretadas como derivadas dos fluidos residuais do magma granodiorítico. Inclusões aquosas tardias de baixa salinidade correspondem ao terceiro tipo de fluido, considerado como água meteórica. As condições de T-P para a deposição do ouro, estabelecidas pelo geotermômetro da clorita e isócoras calculadas a partir dos dados microtermométricos das inclusões fluidas, situam-se entre $300-350^{\circ} \mathrm{C}$ e 1,3-3,8Kb. Os baixos valores da $\mathrm{fO}_{2}$ do fluido mineralizante e a paragênese sulfetada do minério aurífero sugerem que o enxofre encontrava-se em estado reduzido no momento da formação do depósito, condições que favorecem o transporte do ouro como tiocomplexos. Dois eventos de deposição do ouro foram identificados no depósito do Cumaru, ambos relacionados com oxidacão do fluido mineralizante. Inicialmente a oxidação foi causada pela imiscibilidade do fluido aquo-carbônico e pelo abaixamento da $\$ 2$ (sulfetação) nas rochas hospedeiras. A mistura tardia do fluido aquo-carbônico com as salmouras também provocou oxidação do fluido mineralizante, com aumento da fO2 e diminuição do $\mathrm{pH}$, favorecendo a deposição do ouro. Análises de isótopos estáveis forneceram importantes indicações sobre as fontes dos fluidos mineralizantes. Os valores de $\delta^{18} \mathrm{O}$ e $\delta \mathrm{D}$ sugerem mistura de águas metamórficas e magmáticas, enquanto que os dados de $\delta^{13} \mathrm{C}$ são compatíveis com fluidos carbônicos de derivação mantélica. As características geológicas, estruturais e geoquímicas, assim como os dados de inclusões fluidas e isotópicos do depósito do Cumaru são consistentes com depósitos auríferos arqueanos tipo Iode, hospedados em greenstone belts, que ocorrem em zonas de cisalhamento, como também com mineralizações de estilo porfirítico típicas de arcos magmáticos fanerozóicos. Tal situação, sugere que tanto a zona de cisalhamento como a intrusão granodiorítica atuaram na gênese do depósito de ouro mesotermal do Cumaru, incluído em uma nova classe de depósito aurífero denominada aqui de "Iode porfirítico".
\end{abstract}

Palavras-chave: Ouro, metalogênese, mesotermal, granodiorito.

ABSTRACT A new type of gold deposit is described for the Amazon Craton, in the Carajás greenstone belt province. Instead of mesothermal mylonite-hosted lodes or exhalative deposits already recognized in the Carajás Province, the Cumuru gold deposit is hosted by a calc-alkaline $2.82 \mathrm{Ga}$ granodiorite pluton of volcanic arc affiliation. The Cumaru granodiorite is intruded in the horse-tail dilation sites of a shear zone that crosscuts the volcano-sedimentary mylonitic rocks of the Archean Gradaús greenstone belt. The Cumaru gold-bearing quartz veins lie along NE-SW trending fractures at the NW edge of the granodiorite pluton where disseminated ore in a stockwork array of veinlets is associated with the main lodes in a groundmass of hydrothermal phyllic alteration. Three kinds of fluids were identified in the Cumaru quartz veins. An aquo-carbonic fluid, immiscible at the time of ore formation, is interpreted as a metamorphic fluid related to shear zone. The second type of fluid comprises brines within the $\mathrm{H}_{2} \mathrm{O}-\mathrm{NaCl}-\mathrm{KCl}-\mathrm{CaCl}_{2}$ system, interpreted as derived from the granodiorite residual fluids. The third fluid is a low-salinity meteoric water. The T-P conditions for the gold deposition constrained by the hydrothermal chlorite geothermometer and isochores calculated from the fluid inclusions microthermometric data. Values range from 300 to $350^{\circ} \mathrm{C}$ and 1.3 to $3.8 \mathrm{~kb}$. The low fO $\mathrm{falues}_{2}$ of the ore fluids and the gold-sulfide paragenesis suggest that sulfur was in reduced state at the time of ore formation, conditions that favor gold transport as thiocomplexes. Two gold deposition events have been identified in the Cumaru deposit, both related with oxidation of the ore fluids. Initially oxidation was caused by immiscibility of the aquo-carbonic fluid and by wallrock sulfidation with decrease in $\mathrm{fSa}$ of the ore fluids. Subsequent mixing between aquo-carbonic fluid and aqueous brines brought about additional oxidation of the ore fluids with increase in fO2 and decrease in $\mathrm{pH}$, favoring gold precipitation. Stable isotope data place important constraints on the source of the ore fluids: $\delta^{18} \mathrm{O}$ and $\delta \mathrm{D}$ values support the mixing between metamorphic and magmatic water and the $\delta^{13} \mathrm{C}$ data are consistent with mantle-derived carbonic fluids. The cumulative geological, structural, geochemical, fluid inclusions and isotopic data of the Cumaru gold deposit are similar both to Archean greenstone-hosted lode gold deposits that occur in shear zones and to porphyry-style mineralizations typical of Phanerozoic magmatic arcs. Such a situation suggests that both shear zone activation and granodiorite intrusion were involved in the genesis of the Cumaru mesothermal gold deposit, with is here assigned to a new classification of "lode-porphyry gold deposit".

Keywords: gold, metallogenesis, mesothermal, granodiorite

INTRODUCTION The discovery in 1980 of high grade residual gold ore drew a large number of garimpeiros to the Cumaru region in southern Carajás Province of northern Brazil (Fig. 1). The establishment of the Cumaru Project by the Federal Government in the early 80 's to control gold production, led to heightened garimpo activities. However, the deepening of the garimpo pits and the progressive mining of the residual high grade ore led to the dismantling of the Cumaru Project, making way for organized company mining. The search for primary gold ores was started in the early eighties by the Brumadinho Mining but was soon abandoned, and at the end of the decade Gradaús Mining concluded a successful exploration program for both residual and primary quartz vein ore. A small mining plant started in the early 90's.

Two dominant types of gold deposits have been described so far in the Carajás Province: a) mesothermal mylonite-hosted lode deposits such as Babaçu, Lagoa Seca and Sapucaia deposits (Oliveira \& Leonardos 1994, Huhn 1992, Nascimento \& Biagini 1988) related to older greenstone belts, south of the Carajás ridge, and b) probable exhalative gold deposits hosted by younger greenstone belts of the Carajás range such as Salobo, Pojuca and Bahia deposits (Althof et al. 1994, Lindenmayer 1990, Saueressig 1988).

Within the older greenstone belt domain, the Cumaru deposit, 100 $\mathrm{km}$ west of the Redenção Village, has been described as a new gold metallotect (Leonardos et al. 1991, Santos 1995, Santos \& Leonardos 1995). Although the Cumaru deposit is associated with a shear zone, it is hosted by an Archean granitoid intrusion and exhibits many characteristics typical of porphyry $\mathrm{Au}-\mathrm{Cu}$ deposits. This previously unrecognized link highlights a possibly important role for granitoids in the genesis of the Archean lode gold deposits of the region.

GEOLOGICAL SETTING The Cumaru deposit is the largest of a number of mostly small deposits hosted by Archean granitoid stocks that were emplaced in the horse-tail dilation sites of the dextral Serra Ruim shear zone. This shear zone cuts across the southern flank of the Gradaús greenstone belt, an older greenstone belt within the Carajás Province (Fig. 1,2). According to Costa et al. (1995) the Gradaús belt is structured as a transpressive duplex, highlighted by the prominent basal sandstone escarpment of the Rio Fresco Group that discordantly

Universidade Federal do Pará, Centro de Geociências -Campus Universitário do Guamá, 66075-900 Belém-Pará, Brazil. - Tel: (091)211-1207 Fax: (091)211-1609, E-mail: mds@ufpa.br

** Universidade de Brasília, Centro de Desenvolvimento Sustentável - SAS, Quadra 05, Bloco H, $2^{\circ}$ andar, 70070-914 Brasflia-DF, Brazil - Tel: (061)322-2550, (061)321-5001Fax: (061)322-8473, E-mail: unbcds@hotmail.com

*** Department of Geology, Oceanography Centre -University of Southampton, Southampton SO143ZH, UK - Tel: (01703)592067, Fax: (01703)593052, E-mail: rpf@mail.soc.soton.ac.uk

**** Isotope Geosciences Unit, Scottish Universities Research \& Reactor Centre, East Kilbride, Glasgow G750QF, Scotland, UK - Tel: (01355)223332, Fax: (01355)229898, E-mail: m.kerr@surrc.gla.ac.uk 
overlies the greenstone belt. A Proterozoic granite batholith cross-cuts the upper Rio Fresco pelitic rocks that form the core of the duplex.

The southern flank of the Gradaus greenstone belt in the Cumaru area comprises a typical metavolcanic-sedimentary sequence (Fig. 2) of the Gradaus Group (Macambira et al. 1986) which has been included in the Andorinhas Supergroup (DOCEGEO 1988). This unit was metamorphosed under greenschist facies conditions and dislocated by conjugate sets of N-NE strike-slip shear zones dipping to the $\mathrm{W}$ and $\mathrm{NW}$ and marked by a strong mylonitic foliation. The main protoliths of this sequence are flows, tuffs and ignimbrites of felsic, intermediate and mafic composition, together with mixed clastic-chemical metasediments and minor ultramafic rocks. Archean granodiorite batholiths such as the Rio Maria Granodiorite (2.88 Ga U-Pb age, Macambira \& Lancelot 1991) transect the Andorinhas greenstone belt (Medeiros 1987). Small granodiorite plutons of slightly younger age have also been identified in the Gradaus greenstone belt (e.g. Cumaru Granodiorite).

In the Cumaru region, the base of the Gradaus Group is represented by intercalations of meta-andesites, meta-basalts and diabases, plus actinolite and chlorite-talc schists. These rocks pass northwards and upwards into meta-dacites/rhyodacites and meta-andesites at the top of the sequence. Centimetric to metric bands exhibiting variable degrees of mylonitization are commonly intercalated with volcanic rocks with little or no deformation. Meta-pelitic rocks and banded iron-formations are often intercalated with felsic volcanic rocks.

Eastwards, the Gradaus belt is represented by an undeformed plutonic sequence composed of olivine gabbros and diabases and small ultramafic bodies of cumulus serpentinite, peridotite and dunite. This unit was termed the "Guarapará Intrusive Suite" by Macambira et al. (1986) and interpreted as a possible Archean layered complex.

CUMARU GRANODIORITE Under the term "Cumaru Granodiorite", Macambira et al. (1986) included three small plutons of 1 to $2 \mathrm{~km}$ in diameter that were intruded into the Gradaus Group (Fig. 2). The Cumaru stock hosts the main gold mineralization and currently is concealed by the alluvial workings of the Cumaru "garimpo" (no longer active), east of the Serra Ruim shear zone. The stock has an elliptical shape, being elongated in the N-S direction and is bordered to the south by the Rio Maria Granodiorite. The other granitoid stocks are covered by the workings of the Maria Bonita "garimpo", west of the Serra Ruim shear zone. The Maria Bonita stocks are compositionally similar to the Cumaru intrusion, but their striking sigmoidal shapes point to syntectonic emplacement of the plutons.

The Cumaru stock is dominated by gray granodiorite but also incorporates small late-formed bodies of a red monzogranite in its northwestern sector. The rocks display an isotropic, mainly idiomorphic and heterogranular texture formed by euhedral crystals of biotite, hornblende, zoned oligoclase and sphene within a late-formed groundmass of quartz and microcline that commonly show graphic intergrowth. Contact metamorphism has strongly affected the mylonitic volcanic host rocks at the western margin. Emplacement of the Cumaru Granodiorite clearly post-dated the carbonate hydrothermal alteration within sheared volcanic rocks of the Gradaus Group, the carbonatized mylonites being transformed by combined thermal and metasomatic processes into banded skarn comprising alternating lenses of saccharoidal quartz, calcite + tremolite-actinolite + diopside-hedenbergite, and epidote + zoisite + grossular + sphene + apatite.

The contact metamorphism of the host Gradaus Group and the absence of deformation within the pluton clearly indicate that emplacement of the Cumaru Granodiorite post-dated the main deformation events of the Serra Ruim shear zone. Nevertheless, the NE-trending fractures and faults in the northern margin of the pluton are concordant with the Serra Ruim shear splay and suggest a late-tectonic timing for the intrusive event.

The Cumaru Granodiorite samples follow the calc-alkaline trend on an AFM diagram (Fig. 3a), and plot inside the volcanic arc granite field (VAG) on the logRb-logY+Nb diagram (Fig. 3b). Isotopic studies of the Cumaru Granodiorite yielded a $2.54 \mathrm{Ga} \mathrm{Rb}$-Sr age (Lafon \& Macambira 1990) with a ${ }^{87} \mathrm{Sr} /{ }^{80} \mathrm{Sr}$ initial ratio of 0.703 ; a $2.82 \mathrm{Ga} \mathrm{U}-\mathrm{Pb}$ age was also obtained (Lafon \& Scheller 1994). The low initial ratio is consistent with the geological, petrographic and geochemical characteristics of the Cumaru Granodiorite that are typical of the Cordilleran I type (Pitcher 1983).

\section{Au-Cu MINERALIZATION AND WALLROCK ALTERATION}

The Cumaru primary ore occurs as an auriferous sulfide-bearing quartz vein swarm chiefly within the NW margin of the Cumaru stock but also hosted by the felsic volcanic country rocks (Fig. 4). The main lodes are $10-100 \mathrm{~cm}$-wide quartz veins trending $\mathrm{N} 30-70^{\circ} \mathrm{E}$ and dipping 40 $80^{\circ} \mathrm{NW}$, and are hosted by second order extension fractures and faults related to the Serra Ruim shear zone. Although the high grade ore shoots $(>10 \mathrm{ppm})$ are usually restricted to the thicker lodes, disseminated mineralization (1-10 ppm) envelops the lodes as stockwork arrays of $1-10 \mathrm{~mm}$-wide veinlets within the wallrock alteration halo.

The lodes are dominantly brecciated quartz veins comprising angular quartz and pyrite fragments cemented by recrystallized quartz, sericite, calcite and late pyrite. Gold accompanies the sulfide assemblage which is, dominated by pyrite in the lodes as well as in the disseminated ore. The gold is unevenly distributed, occurring either as very tiny particles (20-80 urn) within early pyrite and minor chalcopyrite and bismuthinite, or associated with quartz-filled cracks on the borders of sulfide crystals and aggregates (Fig. 5). Interstitial aggregates of late pyrite, chalcopyrite, magnetite and hematite fill the voids between early larger pyrite fragments. Rare molybdenite occurs with quartz and pyrite along early cracks, possibly representing a higher temperature paragenesis.

The wallrock alteration envelope was mainly formed by pervasive and widespread phyllic alteration, yielding a brecciated quartz-sericite rock comprising quartz fragments in a sericite matrix with minor amounts of chlorite, epidote and pyrite. Propylitic and potassic alteration are evident but are restricted to small portions of the pluton and are overprinted by the phyllic alteration. The Propylitic paragenesis comprises epidote, albite, calcite, together with carbonate-chlorite-pyrite veinlets. Potassic alteration is also restricted to hydrothermal microcline + quartz remnants which are almost completely replaced by phyllic alteration.

Lateritization and supergene enrichment of the Cumaru primary gold ores have yielded high grade secondary ore containing 5-50 ppm gold. Free gold grains are dispersed within a brownish red gossan crust comprising iron oxide/hydroxide and sulfate (jarosite) and containing pods of kaolin and chlorite, quartz fragments and local impregnations of manganese oxides. The gossan passes downwards into partially oxidized primary veins containing relict pyrite and vuggy quartz showing cubic negative-crystal shapes formed by leaching of primary pyrite. Botryoidal gold nuggets are also found in high grade ore, yielding bonanza grades of up to $500 \mathrm{ppm}$.

The Cumaru resource has been quoted at about 17 tonnes of gold (including primary and secondary ores) with a mean in situ grade of 10 ppm (Faraco et al. 1996).

THE ORE FLUIDS In order to characterize the ore-bearing fluids of the Cumaru gold deposit, a comprehensive fluid inclusion study was undertaken on the mineralized quartz veins. The microthermometry was performed on a Linkam THM600 stage attached to a Leitz Diaplan microscope, with the spectroscopic analyses of the volatile phases on selected inclusions being completed using a Jobin Yvonne S3000 laser raman microprobe. The majority of the inclusions were of unsuitable sizes $(<5 \mu \mathrm{m})$ for microthermometric study or were destroyed by fracturing and quartz recrystallization process. Most usable inclusions were generally restricted to the cores of undeformed quartz crystals. Five types of fluid inclusions were recognized as part of the Cumaru fluid system.

Type 1- Aquo-carbonic inclusions $\left(\mathrm{H}_{2} \mathrm{O}-\mathrm{CO}_{2}\right.$ - $\left.\mathrm{NaCI}\right)$ These inclusions are the largest $(5-20 \mu \mathrm{m})$ and by far the dominant ones in the Cumaru quartz veins. They usually occur both along healed cracks and as swarms of randomly distributed inclusions, the latter indicating a possible primary origin (Fig. 6a). At room temperature these inclusions are normally two-phase and display irregular and sometimes elongated shapes with local necking-down features. Halite and less-frequent calcite and prismatic crystals of nahcolite $\left(\mathrm{NaHCO}_{3}\right)$ are the daughter minerals present, but captive carbonates and sulfides (pyrite and chalcopyrite) also occur. The degree of fill (F) in the inclusions is dominantly $0.5-0.7$ but varies continuously from 0.1 up to 0.9 (Fig. 6b), providing strong evidence of unmixing (heterogeneous trapping) of an aqueous phase and a $\mathrm{CO}_{2}$-rich phase immiscible at the time of trapping (Rambozetal. 1982).

The $\mathrm{CO}_{2}$ melting temperatures $\left(\mathrm{TmCO}_{2}\right)$ range from -56.0 to $57.2^{\circ} \mathrm{C}$ with a dominant frequency at $-56.6^{\circ} \mathrm{C}$ (triple point), indicating a pure $\mathrm{CO}_{2}$ phase (Fig. 7a). The single $\mathrm{CO}_{2}$ phase was confirmed by Raman spectroscopic analyses that did not detected any other gases. The carbonic phase homogenized invariably into the liquid state and displayed a conspicuous scattering of homogenization temperature $\left(\mathrm{ThCO}_{2}\right.$ ) from +9.0 to $+30.0^{\circ} \mathrm{C}$ (Fig. $7 \mathrm{~b}$ ). These $\mathrm{ThCO}_{2}$ values correspond to a variation from 0.83 to $1.11 \mathrm{~g} / \mathrm{cm}^{3}$ for the density of the carbonic phase. Clathrate melting (TmClath) in all the $\mathrm{H}_{2} \mathrm{O}-\mathrm{CO}_{2}-\mathrm{NaCl}$ 
inclusions took place before the homogenization of the $\mathrm{CO}_{2}$ vapor phase, at temperatures within the range -4 to $-9.5^{\circ} \mathrm{C}$. Salinities of the aqueous phase calculated from the TmClath values, based on the equation of Parry (1986), varied from 19.0 to $20.6 \mathrm{wt} \%$ eq. $\mathrm{NaCl}$, a very high value when compared to aquo-carbonic fluids of many mesothermal lode gold deposits.

Most $\mathrm{H}_{2} \mathrm{O}-\mathrm{CO}_{2}-\mathrm{NaCl}$ inclusions decrepitated on heating between 250 and $300^{\circ} \mathrm{C}$, before total homogenization $\left(\mathrm{Th}_{\mathrm{T}}\right)$ took place. However, the $\mathrm{Th}_{\mathrm{T}}$ of the $\mathrm{CO}_{2}$-rich (low $\mathrm{F}$ ) and $\mathrm{CO}_{2}$-poor (high $\mathrm{F}$ ) inclusions ranged from 210 to $270 " \mathrm{C}$ (in vapor state) and from 220 to $280^{\circ} \mathrm{C}$ (in liquid state) respectively, pointing to a possible solvus on the $\mathrm{Th}_{\mathrm{T}}$-density space.

Type 2 - Carbonic Inclusions $\left(\mathbf{C O}_{2}\right)$ These inclusions are mostly monophase carbonic inclusions (Fig. 8), although some are $\mathrm{CO}_{2}$-rich inclusions $(\mathrm{F}<0.1)$ in which small amounts of $\mathrm{H}_{2} \mathrm{O}$ could be recognized as a thin film wetting the walls of the inclusion cavities.
The carbonic inclusions generally form swarms of randomly distributed or slightly orientated inclusions. They display rounded shapes, ranging from 5 to $15 \mu \mathrm{m}$ in diameter and are usually associated with the much more abundant aquo-carbonic inclusions. As observed with the aquo-carbonic inclusions, the $\mathrm{CO}_{2}$ phase in the carbonic inclusions is pure (Fig. 7a). The homogenization temperatures of the carbonic phase $\left(\mathrm{ThCO}_{2}\right)$ exhibit a smaller range and overlap the lower-half range $\left(9-12^{\circ} \mathrm{C}\right)$ of the aquo-carbonic inclusions (Fig. $\left.7 \mathrm{~b}\right)$; the values correspond to lower fluid densities of $0.77-0.86 \mathrm{~g} / \mathrm{cm}^{3}$.

The uniform composition of the carbonic phase and the coexistence of the aquo-carbonic and carbonic inclusions within the same microdomains in quartz grains support the interpretation that these later inclusions contain a carbonic end-member produced by the $\mathrm{CO}_{2}-\mathrm{H}_{2} \mathrm{O}$ immiscibility that occurred during the evolution of the aquo-carbonic fluid.
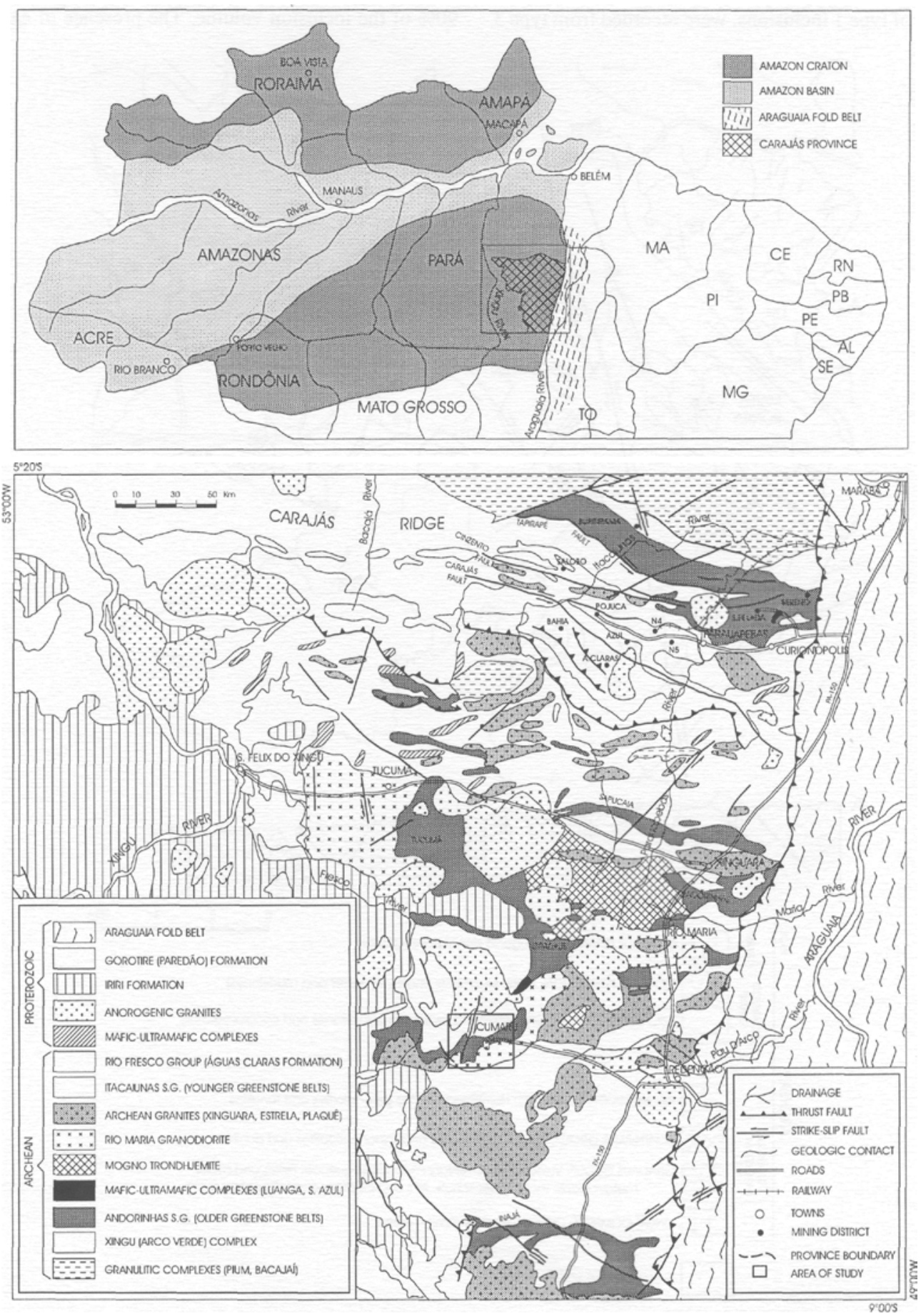

Figurei - Location and geological map of the Carajás Province. Adapted from Faraco et al. (1996), DOCEGEO (1988) and Schobbenhaus et al. (1981). 
Type 3 - Saturated aquo-carbonic inclusions $\left(\mathrm{H}_{2} \mathrm{O}-\mathrm{CO}_{2}\right.$ NaCI-Na $\mathbf{C O}_{3}$ ) These aquo-carbonic inclusions are $\mathrm{H}_{2} \mathrm{O}$-rich brines $(\mathrm{F}>0.9)$ in which the $\mathrm{CO}_{2}$ phase is difficult to detect. They display irregular and rounded shapes and are 5 to $15 \mu \mathrm{m}$ in size. They occur along healed cracks (pseudosecondary inclusions) inside single quartz grains and are associated with type 1 and type 2 inclusions (Fig. 9). The daughter minerals identified in these brines are halite, nahcolite $\left(\mathrm{NaHCO}_{3}\right)$ and $\mathrm{Na}_{2} \mathrm{CO}_{3}$. The latter is indicated by carbonate melting temperatures (TmCarb) of between 2 and $30^{\circ} \mathrm{C}$ with a peak around $10^{\circ} \mathrm{C}$ (Fig. 10a), a feature not recorded in the other aqueous inclusions of the Cumaru deposit. The $\mathrm{Na}_{2} \mathrm{CO}_{3}$ daughter mineral was also identified in the type 1 inclusions (Fig. 10a), though less abundant, with TmCarb near the $10^{\circ} \mathrm{C}$ peak of the type 3 inclusions.

The ice-melting temperatures (Tmlce) of the majority of type 3 inclusions range from -35 to $-20^{\circ} \mathrm{C}$ (with a peak around $-24^{\circ} \mathrm{C}$ ), temperatures markedly lower than Tmlce for the majority of type 1 inclusions (Fig. 10b). Conversely, only two values of Tmlce between -13 and $-11^{\circ} \mathrm{C}$, typical of type 1 inclusions, were recorded from type 3 inclusions. Equally, only a few values of Tmlce around the $-24^{\circ} \mathrm{C}$ peak of the type 3 inclusions were recorded from type 1 inclusions. The TmCarb and Tmlce behavior of type 1 and type 3 inclusions, plus the coexistence of these two types of inclusions in the same micro-domains in quartz grains and the identification of $\mathrm{CO}_{2}$ in type 3 inclusions all demonstrate a close relationship between type 1 and type 3 inclusions. Consequently, type 3 inclusions could be considered the aqueous end-member brine produced by $\mathrm{H}_{2} \mathrm{O}-\mathrm{CO}_{2}$ immiscibility at the time of the aquo-carbonic fluid trapping.

Type 4 - Saturated aqueous inclusions $\left(\mathrm{H}_{2} \mathrm{O}-\mathrm{NaCI}-\mathrm{KCI}-\right.$ $\left.\mathrm{CaCl}_{2}\right)$ These inclusions are the smallest $(<10 \mu \mathrm{m})$ and least abundant in the quartz veins. They occur along healed cracks and trails inside single quartz grains (pseudosecondary inclusions) and are associated with aquo-carbonic inclusions (Fig. 11). They are aqueous brines $(\mathrm{F}>0.9)$ within the $\mathrm{H}_{2} \mathrm{O}-\mathrm{NaCl}-\mathrm{KCl}-\mathrm{CaCl}_{2}$ system with halite daughter mineral and the total solid phases occupying from $20 \%$ to more than $90 \%$ of the inclusion volume. The presence of calcium chloride was

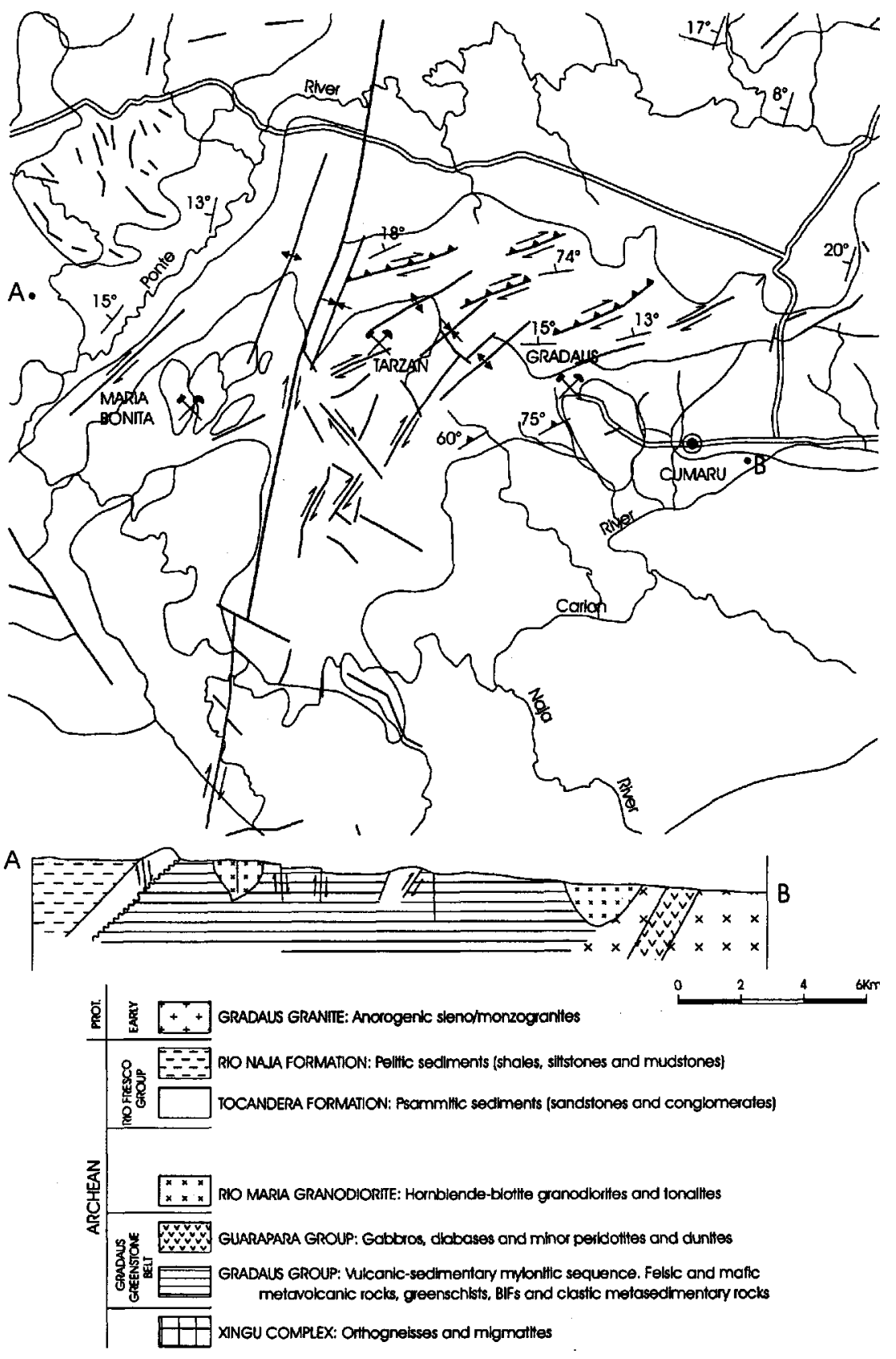

GOLD DEPOST MAP

Figure 2 - Geological map of the southern flank of the Gradaus greenstone belt (Santos 1995). 
indicated by low first-melting temperatures (Tfm around -50 to $-60^{\circ} \mathrm{C}$ ) and final ice-melting temperatures (Tmlce) between -44 and $-31{ }^{\circ} \mathrm{C}$ with a peak around -40 to $-36^{\circ} \mathrm{C}$ (Fig. 12a). Solid phase analyses of these inclusions by scanning electron microscopy confirmed the presence of complex Na-K-Ca chlorides. Halite melting temperatures ( TmNaCl) of 230 to $270^{\circ} \mathrm{C}$ correspond to salinities within the range of 33.6 to $36.0 \mathrm{wt} \%$ eq. $\mathrm{NaCl}$. The Tmlce and $\mathrm{TmNaCl}$ values permit calculation of $\mathrm{NaCl} / \mathrm{CaCl}_{2}$ ratios of between 1 and 1.3 , following Vanko et al. (1988) and William-Jones \& Samson (1990).

The very different composition of the solid phases and the absence of $\mathrm{CO}_{2}$ suggest that the type 4 inclusions are remnants of a separate fluid that had mixed with the aquo-carbonic fluid during the evolution of the Cumaru fluid system.

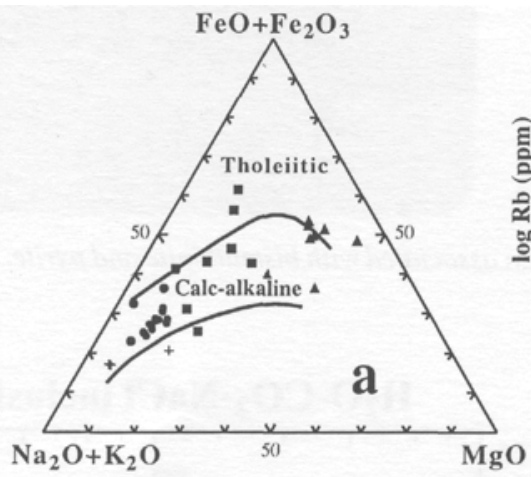

Type 5 - Late aqueous inclusions These inclusions are 1-1 Sum in size and occur along healed cracks and planar arrays which continue across quartz grain boundaries (secondary inclusions). They are both monophase and two-phase inclusions with a degree of fill of around 0.95 . The ice-melting temperatures (Tmlce) of these inclusions range from -12 to $0^{\circ} \mathrm{C}$ (Fig. 12b), which indicates a low-salinity later fluid.

FLUID EVOLUTION Based on the physical characteristics and on the microthermometric fluid inclusion data, three kinds of fluids can be defined for the Cumaru gold-bearing quartz veins. The aquo-carbonic fluid (types 1, 2 and 3 inclusions), is the dominant fluid in the Cumaru gold deposit, represented mainly by type $1 \mathrm{H}_{2} \mathrm{O}-\mathrm{CO}_{2}-\mathrm{NaCl}$ inclusions. The carbonic inclusions (type 2) and the aquo-carbonic brines (type 3 ) are regarded as end-members produced by immiscibility processes (Fig. 13). The presence of pure $\mathrm{CO}_{2}$ and the similar melting

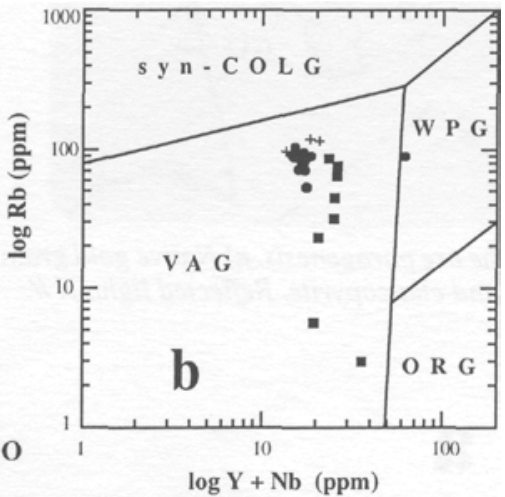

Figure 3 - Distribution of Cumaru Granodiorite and associated volcanic rocks in : a) AFM diagram. Trends after Barker \& Arth (1976). b) Log $\mathrm{Rb}-\log Y+N b$ plot showing the samples within the volcanic arc granite field (VAG). Fields after Pearce et al. (1984). ORG-Ocean chain granites, WPG-Within plate granites, VAG-Volcanic arc granites, Syn-COL-Collision granites, $\bullet$ Cumaru Granodiorite, + Rio Maria Granodiorite, - Felsic volcanic rocks, $\Delta$ Mafic volcanic rocks

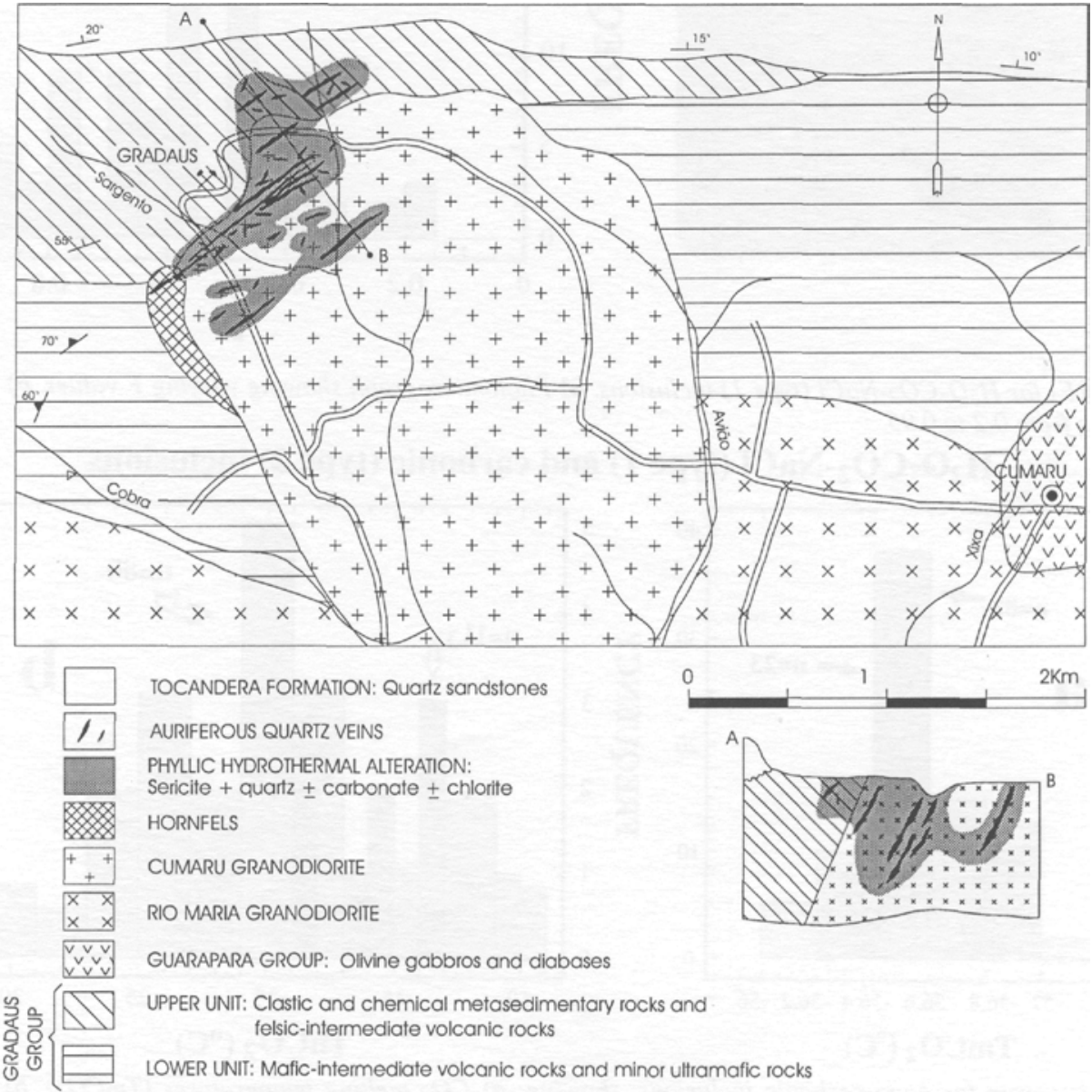

Figure 4 - Geological map of the Cumaru gold deposit (Santos 1995). 

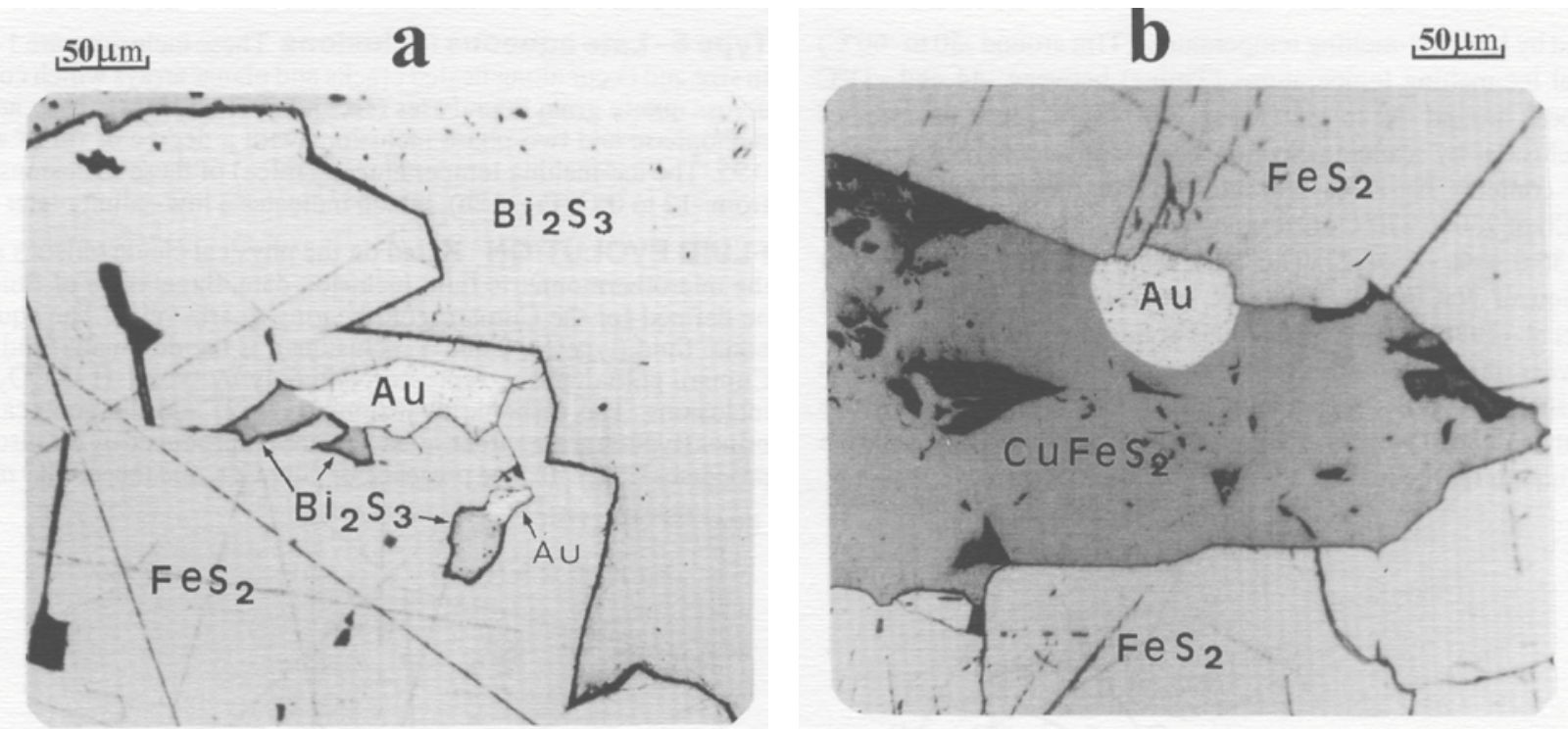

Figure 5 - Photomicrographs of the ore paragenesis. a) Native gold grain associated with bismuthinite and pyrite. Reflected light, $N / /$. b) Native gold gain associated with pyrite and chalcopyrite. Reflected light, $N / /$.
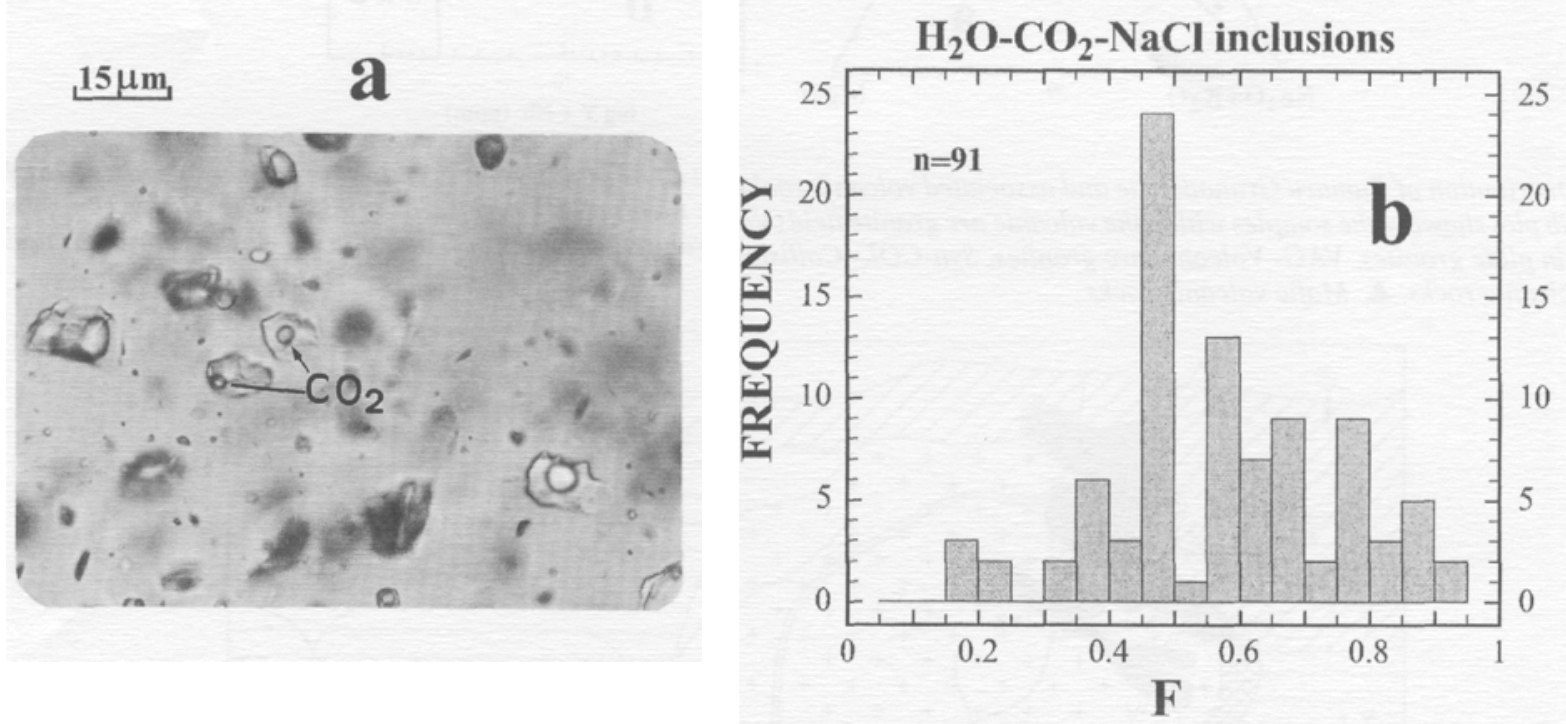

Figure 6 - Degree of fill (F) far $\mathrm{H}_{2} \mathrm{O}-\mathrm{CO}_{2}-\mathrm{NaCl}$ (type 1) inclusions, a) Photomicrograph showing varying $\mathrm{F}$ values, b) Frequency histogram showing $F$ values ranging from 0.2 to 0.95 .

$\mathrm{H}_{2} \mathrm{O}-\mathrm{CO} 2-\mathrm{NaCl}$ (type 1) and carbonic (type 2) inclusions

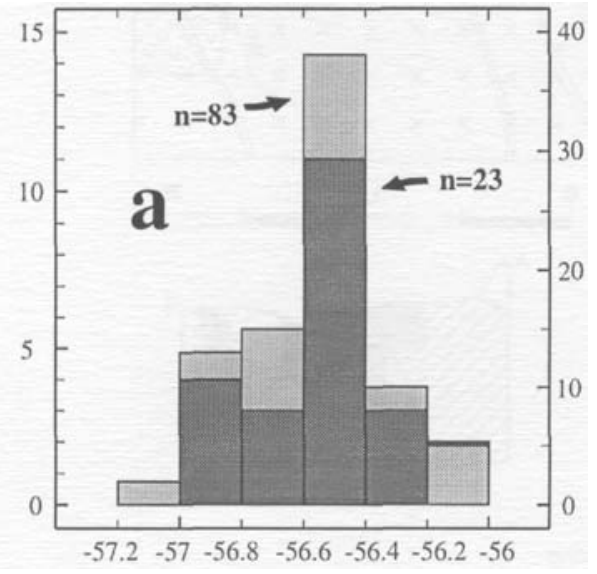

$\mathrm{TmCO}_{2}\left({ }^{\circ} \mathrm{C}\right)$

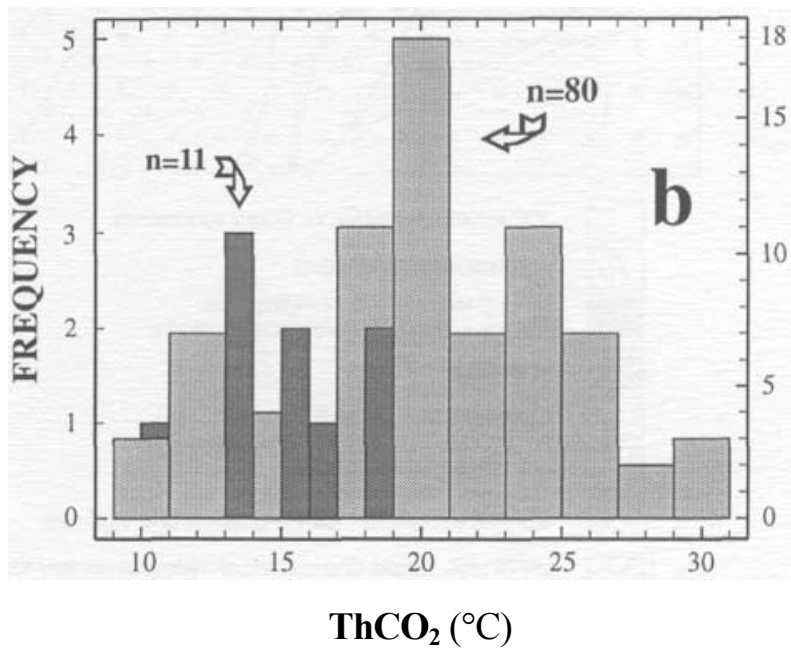

Figure 7 - Frequency histogram for aquo-carbonic inclusions, showing: a) $\mathrm{CO}_{2}$ melting temperatures (TmCO ${ }_{2}$ ). b) $\mathrm{CO}_{2}$ homogenization temperatures $\left(\mathrm{ThCO}_{2}\right.$ ). Vertical scale: right for type 1 inclusions (clear columns) and left for type 2 inclusions (dark columns). 
behavior of ice and $\mathrm{Na}$ carbonate are common features that support a cogenetic origin for these inclusions. Despite their high salinity, the $\mathrm{H}_{2} \mathrm{O}-\mathrm{CO}_{2}-\mathrm{NaCl}$ inclusions are very similar to typical shear-related aquo-carbonic fluids of mesothermal lode gold deposits (Phillips \& Groves 1983, Smith et al. 1984, Ho et al. 1985). Accordingly, it seems reasonable to consider the aquo-carbonic fluid of the Cumaru gold deposit as related to the Serra Ruim shear zone.

A second type of fluid is represented by the $\mathrm{H}_{2} \mathrm{O}-\mathrm{NaCl}-\mathrm{KCl}-\mathrm{CaCl}_{2}$ brine (type 4 inclusions) which displays striking differences in respect to its mode of occurrence, abundance, and P-V-T-X properties when compared to the aquo-carbonic fluid. Furthermore, type 4 inclusions contain aqueous brines devoid of $\mathrm{Na}$ carbonate and $\mathrm{CO}_{2}$, the isochores

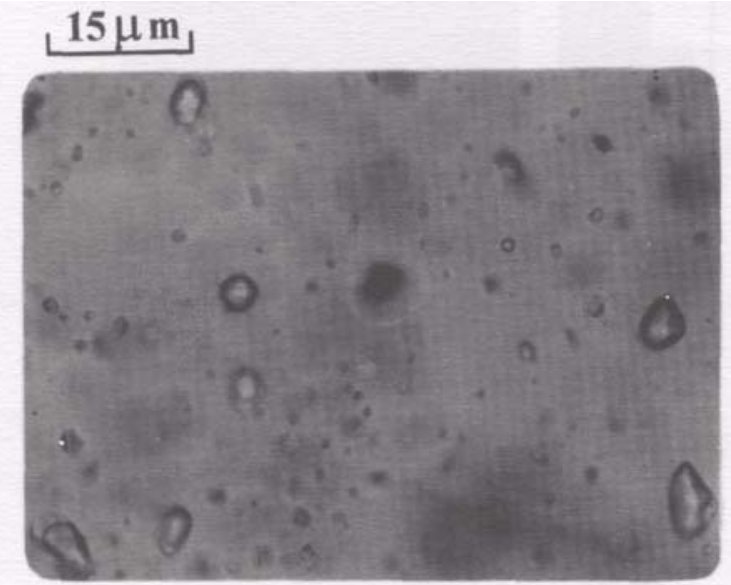

Figure 8 - Photomicrograph of monophase and two-phase carbonic inclusions (type 2 ).

$15 \mu \mathrm{m}$

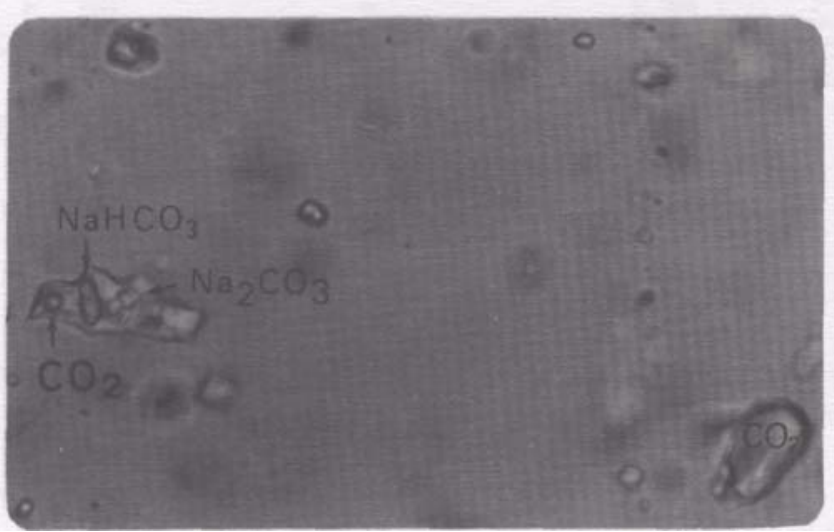

Figure 9 - Photomicrograph of aquo-carbonic brine inclusions (type 3) associated with type 1 inclusions. of which crosscut those of the aquo-carbonic fluids. As these brines occur in granitoid-hosted quartz veins, and porphyry deposits in granitoid cupolas are well-known brine-producing systems (Wilson et al. 1980, Weisbrod 1981, Roedder 1984), it is reasonable to hypothesize that type 4 inclusions are remnants of a fluid derived from the residual magma of the Cumaru granodiorite pluton. The Cumaru Granodiorite is a late-tectonic pluton emplaced in the Serra Ruim shear zone, and introduction of thus the shear-related aquo-carbonic fluids probably preceded and overlapped with influx of the granodiorite-related aqueous brine. Mixing of the two fluids probably took place along the healed cracks as suggested by their close association, thus effectively increasing the salinity of the aquo-carbonic fluid.

The low-salinity late aqueous inclusions represent a third type of fluid, possibly almost pure meteoric water that had circulated along later cracks.

TRANSPORT AND DEPOSITION OF THE GOLD T-P conditions of the ore deposit formation The ore fluid studies described above help to place some constraints on the physicochemical parameters that controlled the solubility and destabilization of the gold complexes ( $\mathrm{T}, \mathrm{P}, \mathrm{fO}_{2}, \mathrm{fS}_{2}$ and $\mathrm{pH}$ ) and hence can be used to model gold transport and deposition. However, because of the limited data concerning total homogenization of the aquo-carbonic fluid $\left(\mathrm{Th}_{\mathrm{T}}\right)$, the use of a geothermometer was necessary to further constrain the temperature conditions which prevailed during gold deposition and trapping of the ore-bearing fluids. Microprobe analyses of hydrothermal chlorite in the altered wallrock were utilized following the approach developed by Cathelineau (1988) who established that $\mathrm{Al}$ in occupancy of the tetrahedral sites of the chlorite increases linearly with crystallization temperature according to the relationship: $\mathrm{T}\left({ }^{\circ} \mathrm{C}\right)=$ 321.98( $\left.\mathrm{A}^{\mathrm{IV}}\right)-61.92$. Chlorite analyses of the Cumaru deposit indicated temperatures within the range $300-350^{\circ} \mathrm{C}$ with a peak at around $340-350^{\circ} \mathrm{C}$ (Fig. 14a).

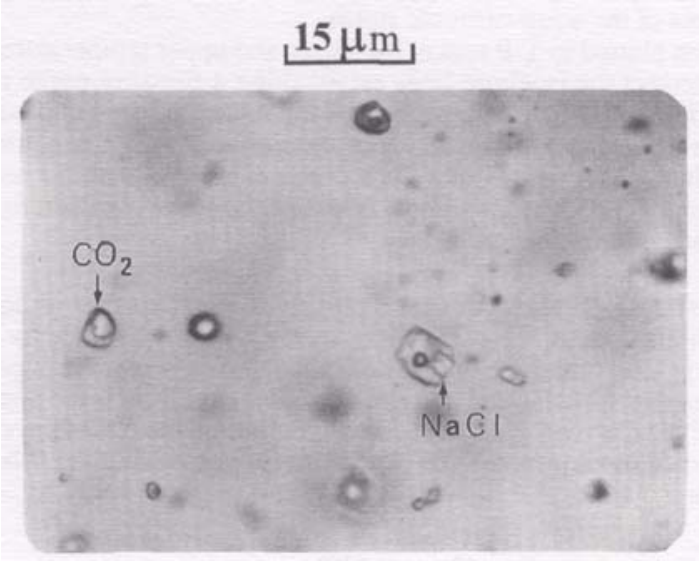

Figure 11 - $\mathrm{H} 2 \mathrm{O}-\mathrm{NaCl}-\mathrm{KCl}-\mathrm{CaCl} \mathrm{Cl}_{2}$ brine inclusions (type 4) associated with type 1 inclusions.

\section{$\mathrm{H}_{2} \mathrm{O}-\mathrm{CO}_{2}-\mathrm{NaCl}$ (type 1) and aquo-carbonic brines (type 3 ) inclusions}
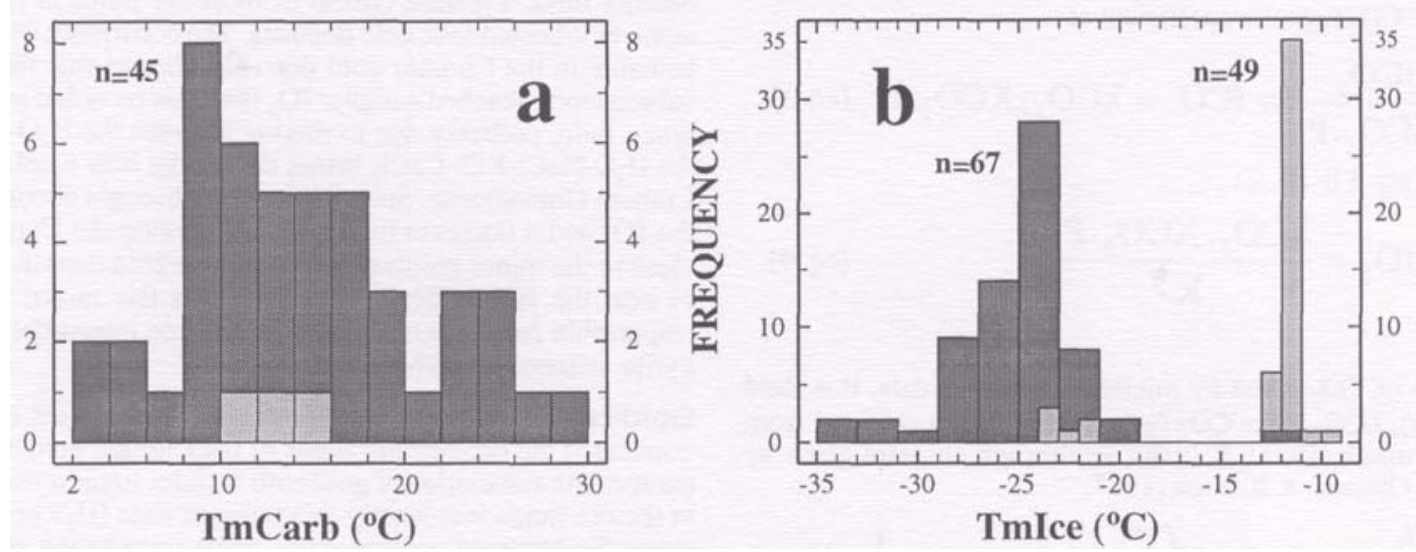

Figure 10 - Frequency histogram for type 1 (light columns) and type 3 (dark columns) inclusions, showing: a) Melting temperatures of Na carbonate (TmCarb). b) Melting temperatures of ice (Tmlce). 

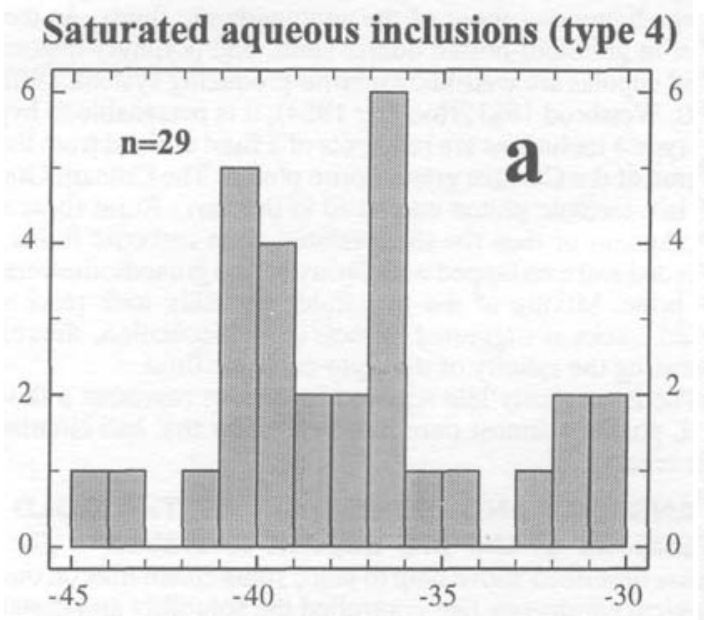

Tmlce $\left({ }^{\circ} \mathbf{C}\right)$

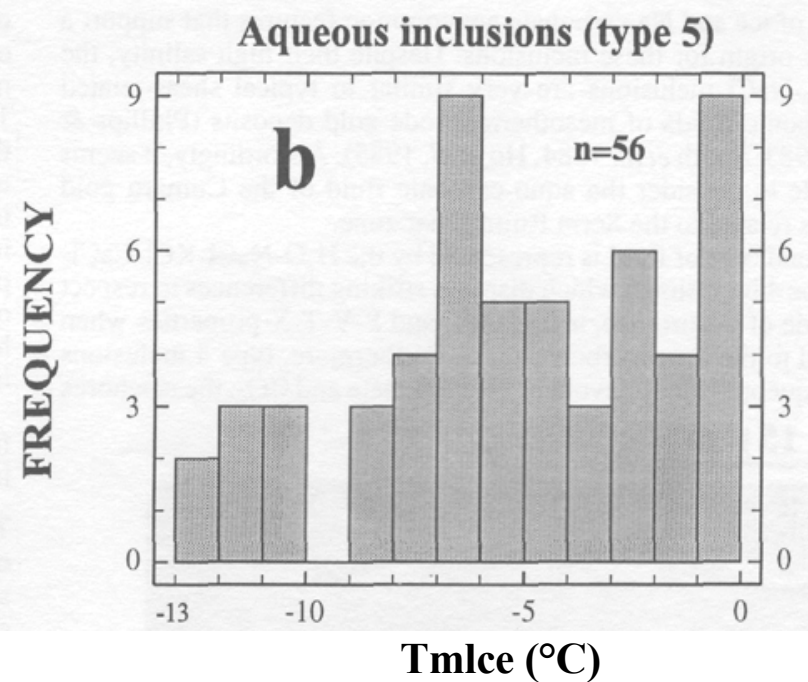

Figure 12 - Frequency histogram of ice-melting temperatures (TmIce). a) Saturated aqueous inclusions (type 4). b) Late aqueous inclusions (type 5).

The pressure regime for the gold deposition was assessed through isochores calculated from the microthermometric data of the fluids described above by using the equation of state of Brown \& Lamb (1989). The isochores A, B and D (Fig. 14b) cover the whole density range of the type 1 inclusions, whereas the isochore $\mathrm{C}$ corresponds to carbonic inclusions (type 2) which display the lowest density values and hence the lowest slope of all the isochores. The highest density values and thus the highest isochore slope is presented by the isochore $\mathrm{S}$ of the aqueous brines (type 4 inclusions) which cross-cuts the isochores of the aquo-carbonic fluids.

When plotted in T-P space, the lower and upper temperature intervals intersect the isochore lines establishing a pressure range of 1.3$3.8 \mathrm{~kb}$ (Fig. 14b). The intersection of the aquo-carbonic and aqueous brine isochores could theoretically determine the T-P conditions of these fluids. The ranges of values obtained by this method are 285$400^{\circ} \mathrm{C}$ and $1.3-3.1 \mathrm{~kb}$ that broadly overlaps the range obtained from the chlorite geothermometer.

Fluid redox state As the solubility of metal species in aqueous hydrothermal solutions is largely affected by oxygen fugacity $\left(\mathrm{fO}_{2}\right)$, the redox state of the ore fluid is critical to the transport and deposition of the metals. Considering that the aquo-carbonic fluid is the dominant fluid of the Cumaru gold deposit, evaluation of the C-O-H system is appropriate to address the $\mathrm{fO}_{2}$ of the ore fluid, by using the following equations:

$$
\mathrm{C}+\mathrm{O}_{2} \Leftrightarrow \mathrm{CO}_{2}
$$$$
\text { where, } \quad \mathrm{K}=\frac{\mathrm{fCO}_{2}}{\mathrm{fO}_{2}} \Rightarrow \mathrm{fO}_{2}=\frac{\mathrm{fCO}_{2}}{\mathrm{~K}}
$$

Defining the $\mathrm{CO}_{2}$ fugacity coefficient as

$$
\lambda \mathrm{CO}_{2}=\frac{\mathrm{fCO}_{2}}{\mathrm{XCO}_{2} \cdot \mathrm{P}} \Rightarrow \mathrm{fCO}=\lambda \mathrm{CO}_{2} \cdot \mathrm{XCO}_{2} \cdot \mathrm{P}
$$

Substituting eq. 3 in eq. 2 :

$$
\mathrm{fO}_{2}=\frac{\lambda \mathrm{CO}_{2} \cdot \mathrm{XCO}_{2} \cdot \mathrm{P}}{\mathrm{K}}
$$

where :

$\mathrm{XCO}_{2}$ is $\mathrm{Mol} \%$ of $\mathrm{CO}_{2}$ given by microthermometric data, $\mathrm{P}$ is fluid pressure (in bar), $\lambda \mathrm{CO}_{2}$ is the $\mathrm{CO}_{2}$ fugacity coefficient obtained from Ryzhenko \& Volkov (1971), $\mathrm{K}$ is the equilibrium constant given by the equation of Ohmoto \& Kerrich (1977):

$\log K=\frac{20586}{T}+0.041+0.028\left(\frac{P-1}{T}\right), \mathrm{T}$ in ${ }^{\circ} \mathrm{K}$ and $\mathrm{P}$ in atm.

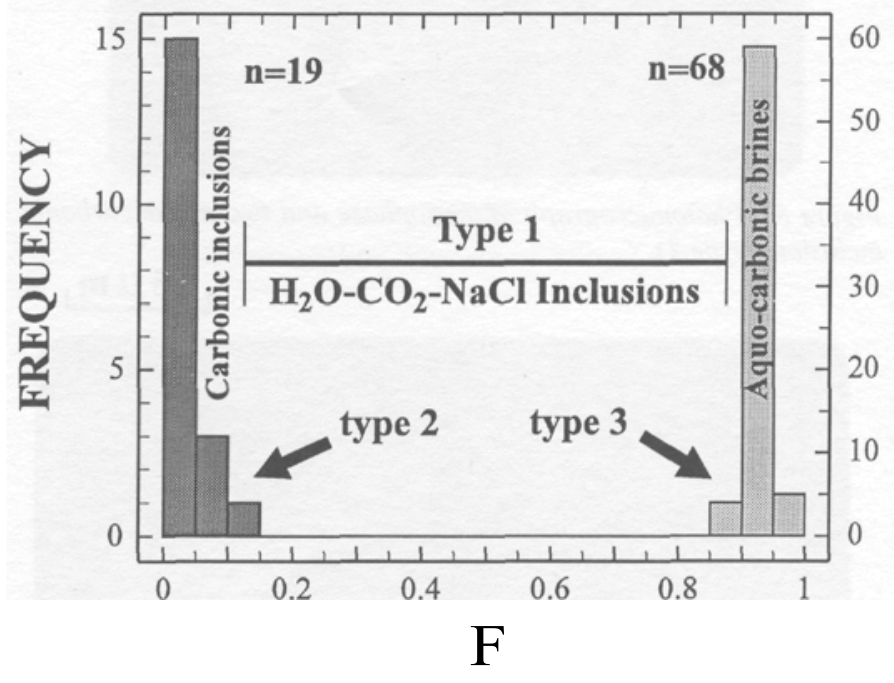

Figure 13- Frequency histogram of degree of fill (F)for type 2 and 3 inclusions.

The $\mathrm{fO}_{2}$ of the Cumaru ore fluids, thus calculated by equation 4 for a temperature range of $300-350^{\circ} \mathrm{C}$ at pressures of $1.3-3.8 \mathrm{~kb}$, varies from $10^{-34}$ to $10^{-30}$ bar. On a $\operatorname{logfO} \mathrm{O}_{2}$-T diagram (Fig. 15), the $\mathrm{fO}_{2}$ values of the Cumaru $\mathrm{H}_{2} \mathrm{O}-\mathrm{CO}_{2}$ fluid plot slightly above the quartz-fayalitemagnetite buffer (QFM) and well below the hematite-magnetite buffer (HM), thus demonstrating the relatively reduced nature of the goldbearing fluid, a feature typical of most ore fluids in Archean greenstone-belt-hosted lode gold deposits. The occurrence of magnetite and hematite in the Cumaru gold deposit indicates that the fluid system subsequently reached a higher $\mathrm{fO}_{2}$ than that recorded in the aquo-carbonic fluid, probably due to mixing between the $\mathrm{H}_{2} \mathrm{O}-\mathrm{CO}_{2}$ fluid and the $\mathrm{H}_{2} \mathrm{O}-\mathrm{NaCl}-\mathrm{KCl}-\mathrm{CaQ}$ brines during the later emplacement of the Cumaru Granodiorite. Such fluid mixing brought about an increase in the $\mathrm{fO}_{2}$ and a decrease in $\mathrm{pH}$ values, moving the Cumaru ore fluids close to the minor group of Archean lode gold deposit that formed at or near the HM buffer (Fig. 15). It was this mixed fluid that was responsible for the introduction of the late interstitial aggregates of pyrite, magnetite and hematite.

Gold-transporting complexes The reduced conditions that dominated the ore-bearing fluids of the Cumaru gold deposit and the paragenetic association of gold with sulfides suggest the sulfur present in the ore fluids was mostly in a reduced state $\left(\mathrm{H}_{2} \mathrm{~S}\right.$ or HS-). Furthermore, the common occurrence of white mica as the main mineral in the hydrothermal paragenesis and the absence of clay minerals imply a neutral to slightly alkaline nature of the ore fluids (Romberger, 1988). 


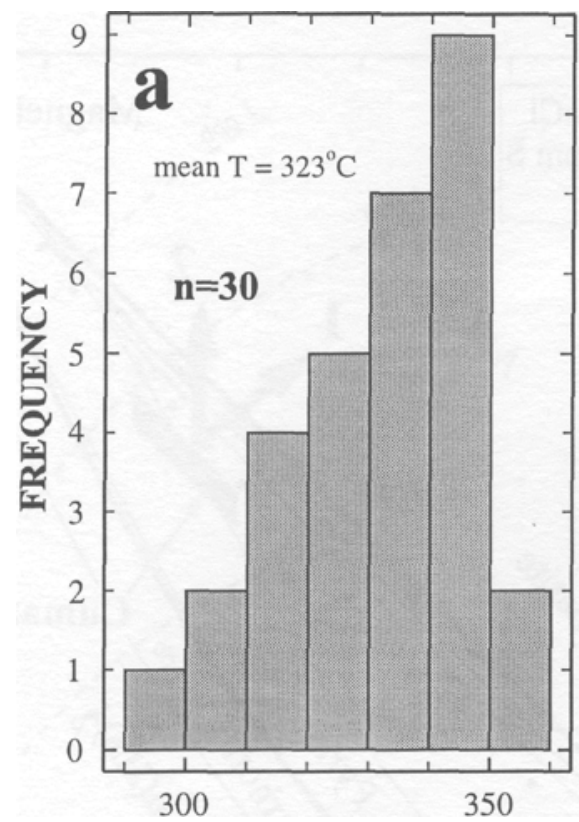

TEMPERATURE $\left({ }^{\circ} \mathrm{C}\right)$

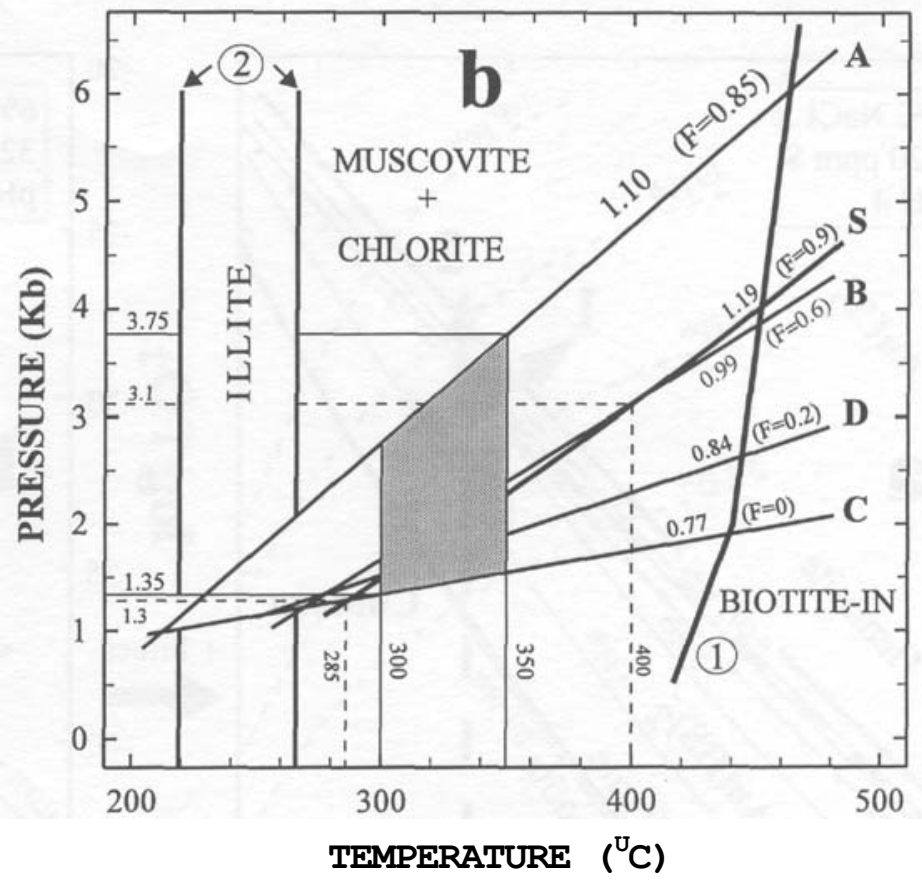

Figure 14 - Temperature and pressure regime for the Cumaru gold deposit, a) Temperature range obtained from chlorite geothermometry after Cathelineau (1988). b) T-P range (stippled area) within the muscovite + chlorite stability field. The $300-350^{\circ} \mathrm{C}$ range was calculated from the chlorite geothermometer whereas the $285-400^{\circ} \mathrm{C}$ range was obtained by intersection of the isochores $B$ and $C$ with $S$. The isochores $A, B$ and $D$ are from type 1 inclusions, the isochore $C$ is from type 2 inclusions and isochore $S$ represents type 4 inclusions. The numbers on the isochores correspond to density values of the fluids and the degree of fill $(F)$ of the inclusions. Curve 1 (biotite-in) after Nitsch (1970) and domain 2 (illite) after Hoffman \& Hower (1979).

Based on these data, the mineralizing fluids of the Cumaru gold deposit can be characterized broadly as $\mathrm{CO}_{2}$-rich, near-neutral, low-fO ${ }_{2}$ aqueous fluid with $\mathrm{T}=300-350^{\circ} \mathrm{C}$. Experimental gold solubility studies, under these conditions, have demonstrated the importance of thiocomplexes as ligands for gold (Seward 1984,1989). In logfO ${ }_{2}$-T space (Fig. 16), the $\mathrm{fO}_{2}$ range of the main-stage Cumaru ore fluid plots in the stability field of $\mathrm{Au}(\mathrm{HS})_{2}$ - for near-neutral solutions, where high gold solubilities (up to lOOppb) are attained. The solubility of gold as $\mathrm{AuCl}_{2}-$, however, would be much lower $(<0.1 \mathrm{ppb})$. Therefore gold transport in the Cumaru deposit was dominantly as $\mathrm{Au}(\mathrm{HS})_{2-}$ or $\mathrm{HAu}(\mathrm{HS})_{2}{ }^{\circ}$, with little or no contribution by $\mathrm{AuCl}_{2}$ - (Seward 1984, 1989).

Mechanism of gold deposition Any change in physico-chemical parameters that reduces stability of $\mathrm{Au}(\mathrm{HS})_{2^{-}}$or $\mathrm{HAu}(\mathrm{HS})_{2}{ }^{\circ}$ may cause precipitation of gold from an ore fluid. Two gold deposition events have been identified (Fig. 16):

1-Initially gold precipitation was caused by immiscibility between liquid and vapor phases of the shear-related aquo-carbonic fluid that led to loss of reduced sulfur species to the vapor phase. This process brought about oxidation of the residual fluid and consequent gold precipitation. Fluid-rock interaction, including wallrock sulfidation, also cause increase in $\mathrm{fO}_{2}$ and decrease in $\mathrm{fS}_{2}$ of the ore fluid thus favoring gold deposition.

2- Later mixing between the aquo-carbonic fluid and aqueous brines caused oxidation of the ore fluid with an increase in $\mathrm{fO}_{2}$ and decrease in $\mathrm{pH}$ which thus favored deposition of gold and development of the pyrite-magnetite-hematite assemblage as interstitial aggregates (Fig. 16).

SOURCES OF THE ORE FLUIDS The nature of the source reservoirs of the mineralizing fluids was addressed through evaluation of the stable isotope signatures of the fluid components $\left(5^{18} \mathrm{O}_{\mathrm{H} 20}\right.$, $5 \mathrm{D}_{\mathrm{H} 20}$ and $\left.5^{13} \mathrm{C}_{\mathrm{C} 02}\right)$, the analyses being carried out at the Scottish Universities Research and Reactor Centre (SURCC) in Glasgow, UK (table 1).

On a oD- $8{ }^{18} \mathrm{O}_{\mathrm{H} 20}$ diagram (Fig. 17a), the samples of the Cumaru gold deposit plot inside the metamorphic water field and Archean ore fluid field that overlap the low-OD side of the metamorphic water field. The samples also plot inside or near the boundary of the fields of magmatic water, juvenile water and Santa Rita porphyry fluid that overlap the low-oD side of the metamorphic water field (Fig. 17a).

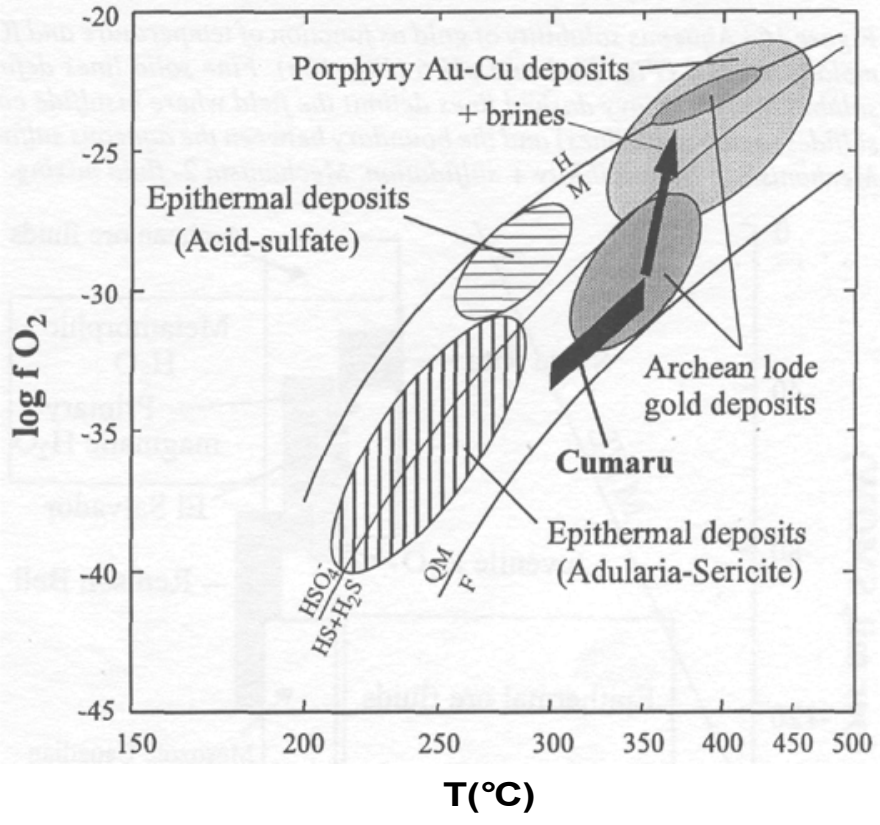

Figure 15 - T-fO2 diagram showing the redox state of the ore fluids from the Cumaru gold deposit (black field) and its relationship with the quartz-fayalite-magnetite $(Q-F-M)$ and hematite-magnetite (H-M) buffers. Also shown are T-fO2 range of the main gold deposit types. Adapted from Huston \& Large (1989).

Such a ôD-ô ${ }^{18} \mathrm{O}_{\mathrm{H} 2} \mathrm{O}$ pattern is consistent with mixing of metamorphic and magmatic fluids as deduced from the fluid inclusion data. The affinity of the Cumaru ore fluids with magmatic water and porphyry fluids is obvious, but a potential overlap with metamorphic water are also evident, suggesting that both these types of fluids could have contributed to the genesis of the Cumaru deposit. Furthermore, the plots of the Cumaru deposit display a vertical spread similar to magmatic and juvenile waters. The low values of $\delta^{18} \mathrm{O}_{\mathrm{H} 2 \mathrm{O}}$ (from 4 to $6 \% \mathrm{o}$ ) 

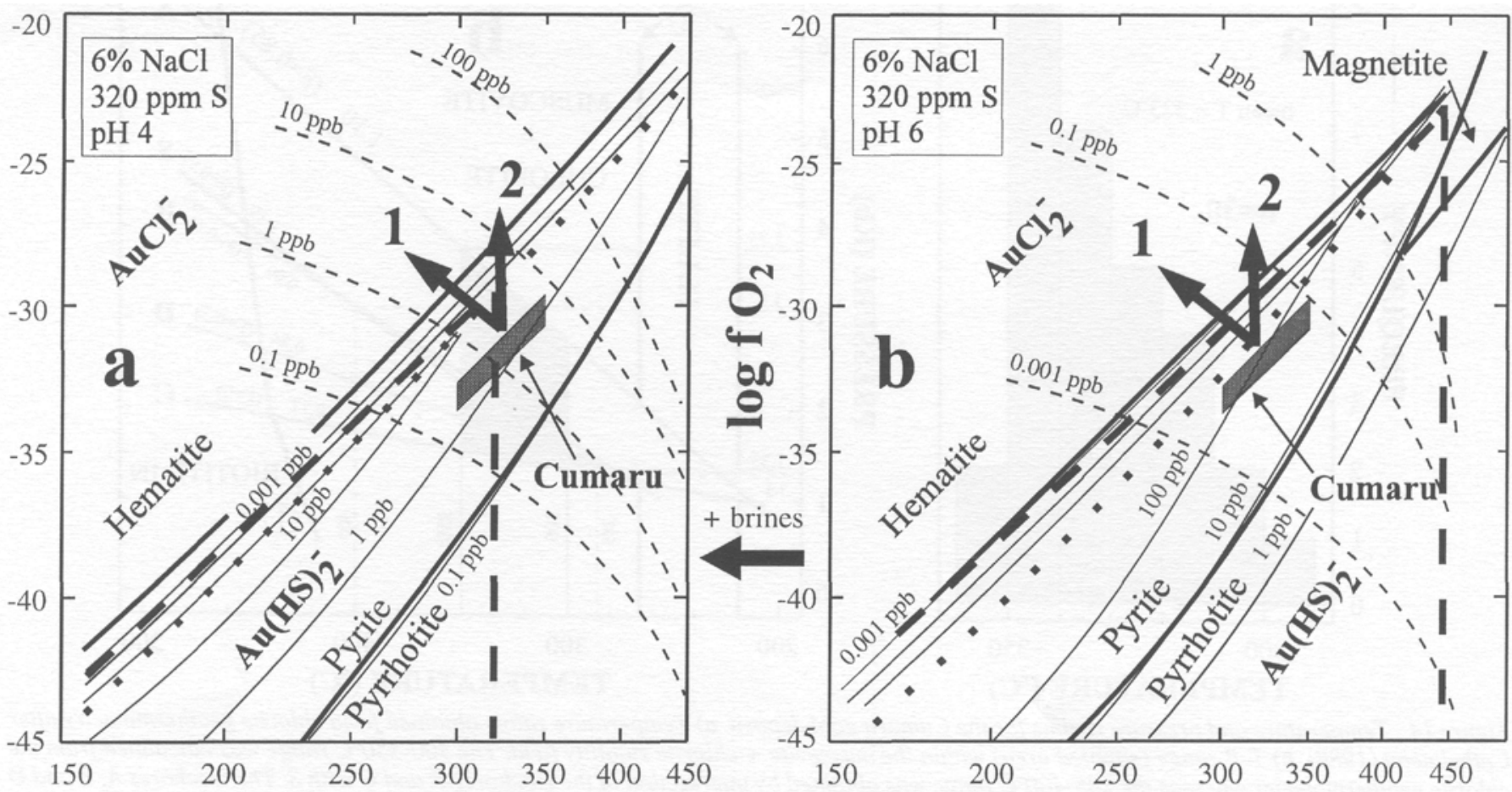

Figure 16 - Aqueous solubility of gold as function of temperature and $\mathrm{fO}_{2}$ in solution containing $6 \mathrm{wt} \% \mathrm{NaCl}$ (1 molal) and $320 \mathrm{ppm}$ sulfur (0.01 molal), at pH 4 (Fig. 16a) and pH 6 (Fig. 16b). Fine solid lines define bisulfide solubilities and fine dashed lines depict choride complexes solubilities. The heavy dashed lines delimit the field where bisulfide complexes predominate. Also shown are stability fields of iron oxides and sulfides (heavy solid lines) and the boundary between the aqueous sulfate and sulfide fields (heavy dotted line). Adapted from Romberger (1990). Mechanism 1-immiscibility + sulfidation. Mechanism 2-fluid mixing.
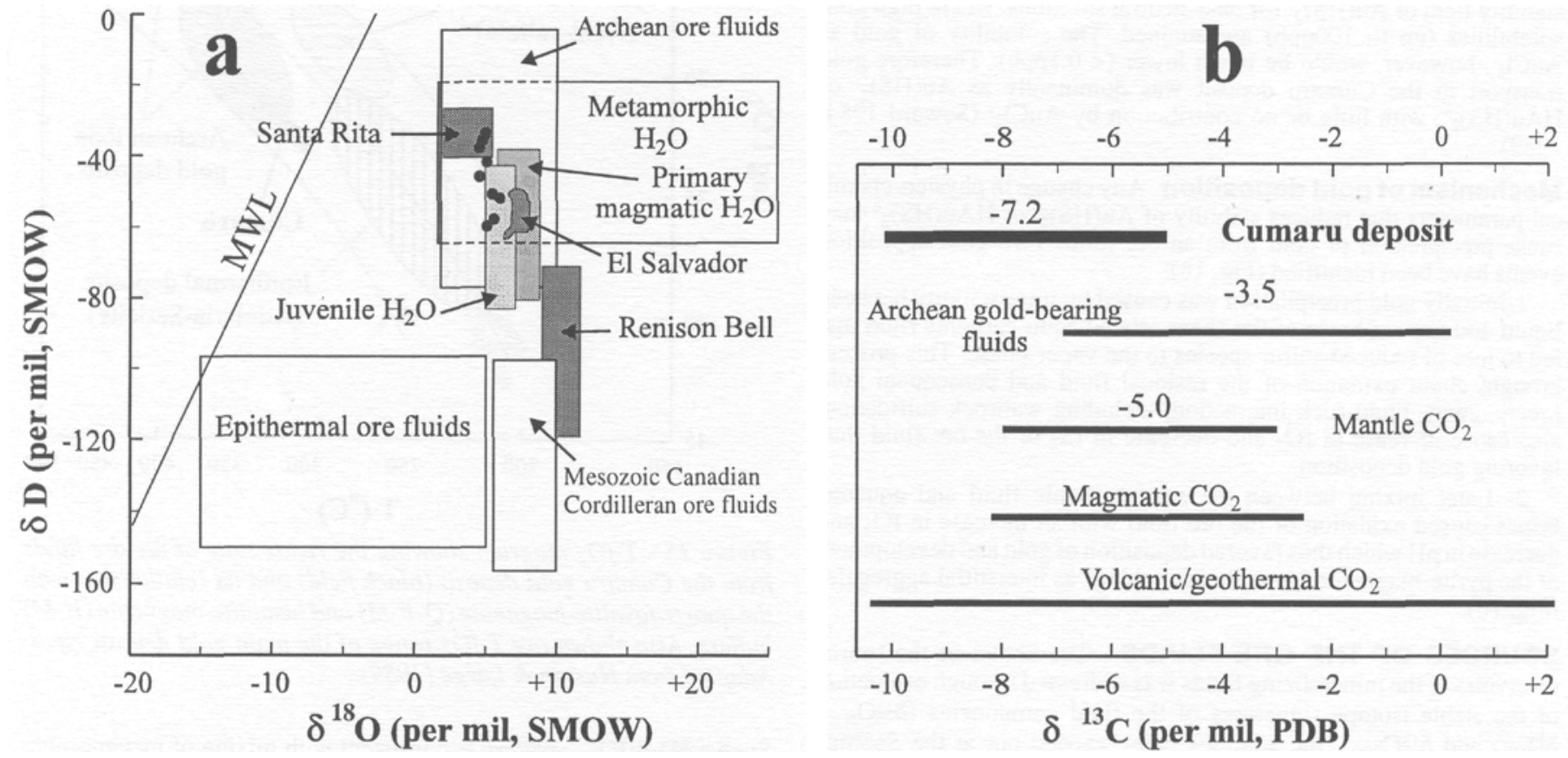

Figure 17 - Stable isotopic data for the mineralized fluids of the Cumaru gold deposit, a) Plot of $\delta$ D values versus $\delta^{18} \mathrm{OH}_{2} \mathrm{O}$ values (black dots). Also shown are the isotopic compositions of primary metamorphic and magmatic waters, and juvenile water obtained from Taylor (1974), Archean ore fluids (Kerrich, 1989; Golding \& Wilson, 1988), Mesozoic Canadian Cordilleran ore fluids (Nesbitt \& Muehlenbachs, 1988) and epithermal ore fluids (Field \& Fifarek, 1985). The isotopic composition of the porphyry deposits fluids (dark stippled fields) are from Ohmoto (1986). $M W L=$ meteoric water line, $b) \delta^{13} \mathrm{C}$ range from fluid inclusion $\mathrm{CO}_{2}$ in quartz veins of the Cumaru gold deposit. Also shown are the range for Archean gold-bearing fluids (Colvine et al. 1988) and for mantle, magmatic and geothermal fluids obtained respectively from Kyser (1986), Taylor (1986) and Field \& Fifarek (1985). Mean values are also illustrated. 


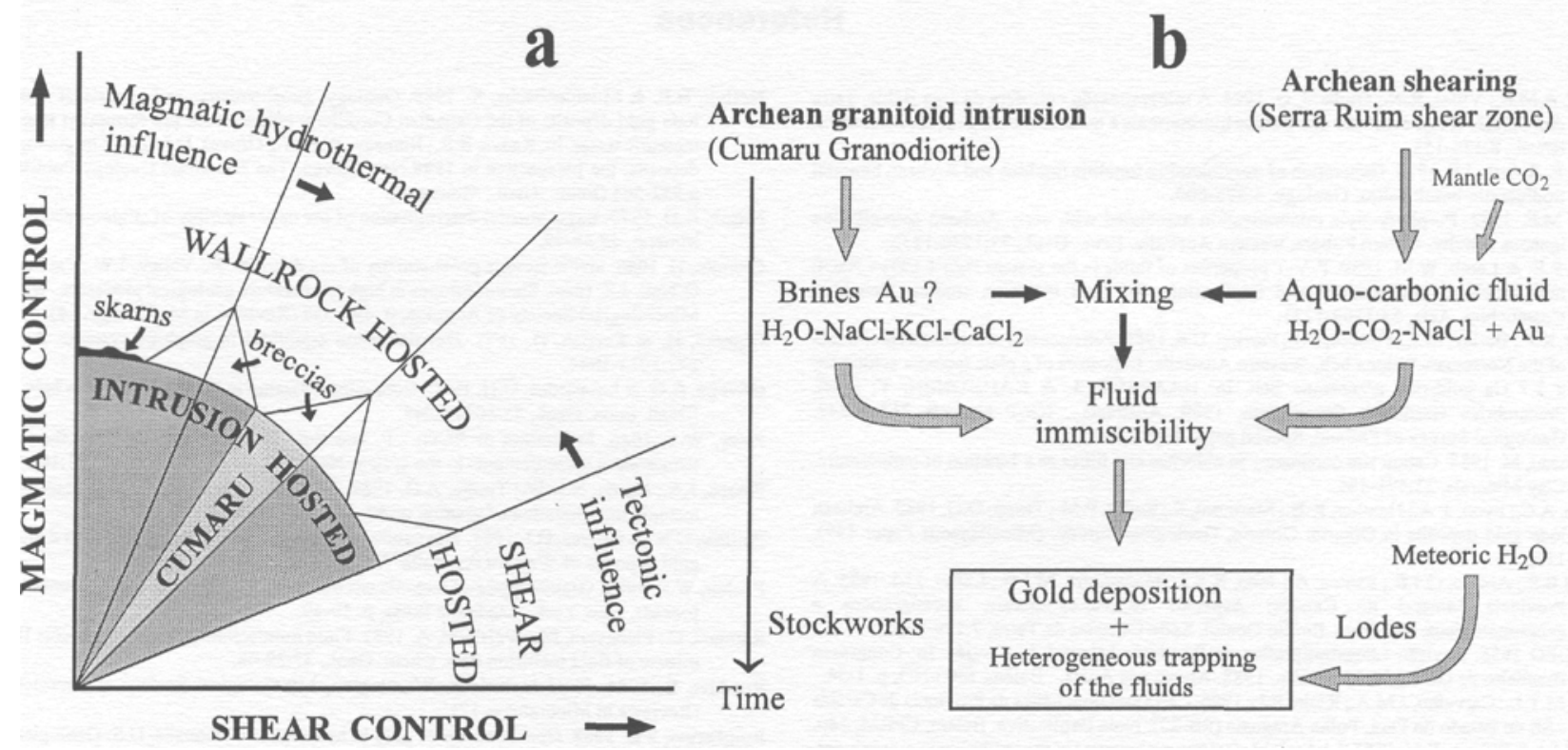

Figure 18 - Genetic model of the Cumaru gold deposit, a) Magmatic versus tectonic influence for hydrothermal gold deposits, showing the hybrid character of the Cumaru deposit between the lode deposits in shear zones and the porphyry deposits in granitoid cupolas. Adapted from Mason (1992). b) Fluid evolution in the lode-porphyry model proposed for the Cumaru gold deposit.

Table 1-Isotope analyses of $\delta D$ and $\delta^{13} \mathrm{C}$ in inclusion fluids and $\delta^{18} \mathrm{O}$ in vein quartz of the Cumaru gold deposit. Values of fluid $\delta^{18} O$ reconstructed from quartz $\delta^{18} \mathrm{O}$ are also given as $\delta^{18} \mathrm{O}_{\mathrm{H} 2 \mathrm{O}}$, calculated by equation of Matsuhisa et al. (1979), as following: ô Omo = $\delta^{18} O_{\text {qtz }}-3.34\left(10^{6} / T^{2}\right)+3.31$; mean $T=323^{\circ} \mathrm{C}\left(596^{\circ} \mathrm{K}\right)$ calculated by chlorite geothermometer.

\begin{tabular}{|c|c|c|c|c|c|}
\hline \multirow[b]{2}{*}{ Samples } & \multicolumn{3}{|c|}{ FLUID INCLUSION H ${ }_{2} \mathrm{O}$} & \multirow{2}{*}{$\begin{array}{c}\text { QUARTZ } \\
\delta^{19} 0 \\
\text { WSMOW }\end{array}$} & \multirow{2}{*}{$\begin{array}{c}\text { FLUID INCLUSION } \mathrm{CO}_{2} \\
\delta^{\delta^{13} \mathrm{C}} \\
\text { SOPDB }_{0}\end{array}$} \\
\hline & $\begin{array}{c}\mathrm{H}_{2} \mathrm{O}^{+} \\
\text {umoles } \mathrm{mg}^{-1}\end{array}$ & $\begin{array}{l}8^{110} 0^{\circ} \\
\text { xaSMOW }^{2}\end{array}$ & $\begin{array}{c}\text { SD } \\
\text { \%oSMOW }\end{array}$ & & \\
\hline $18 / 80.45$ & 0.08 & 6,0 & .52 & 12.1 & -5.02 \\
\hline $18 / 120.9$ & 0.11 & 6,0 & .52 & 12.1 & .8 .28 \\
\hline $3 / 52.5$ & 0.07 & 5,6 & .58 & 11.7 & too small \\
\hline $108 \mathrm{a}$ & 0.12 & 4,7 & .36 & $\begin{array}{l}11.1 ; \\
108\end{array}$ & too small \\
\hline $108 \mathrm{~b}$ & 0.09 & 5,0 & .34 & 11.1 & -5.29 \\
\hline $7 / 95.2$ & 0.07 & 4,6 & -46 & 10.7 & .7 .36 \\
\hline $110 \mathrm{~b}$ & 0.05 & 5,5 & .51 & 11.6 & -10.20 \\
\hline $8 / 116$ & 0.10 & 5,1 & .42 & 11.2 & -7.12 \\
\hline $6 / 147.2$ & 0.10 & 5,1 & .60 & 11.2 & -7.09 \\
\hline $6 / 139.9$ & 0.11 & 4,6 & -38 & 10.7 & too small \\
\hline Averages & & $5.2 \pm 0.7$ & $-47 \pm 11$ & $11.3 \pm 0.7$ & $-7.2 \pm 3.67$ \\
\hline
\end{tabular}

could be evidence of surface (meteoric) water infiltration represented by the type 5 inclusions.

The $\delta^{18} \mathrm{C}$ composition of $\mathrm{CO}_{2}$ extracted from inclusion fluids varies from -5.02 to $-10.20 \%$ (mean of $-7.2 \pm 3.6 \%$ ) which is slightly lower than most values for Archean gold-bearing fluids but similar to geothermal $\mathrm{CO}_{2}$ with a likely magmatic deep crustal and/or mantle provenance (Fig. 17b).

GENETIC MODEL AND CONCLUSIONS The data presented in the previous sections demonstrate that the Cumaru gold deposit displays characteristics of both Archean lode deposits and Phanerozoic porphyry deposits. The occurrence of shear-related quartz veins in greenstone belt with evidence of metamorphic-derived aquo-carbonic mineralizing fluids is typical of Archean lode deposits. On the other hand, the Au-Cu-Bi-Mo metal association, and the presence of stockworks containing brine inclusions and hosted by granitoid cupolas correlate with a porphyry model. In order to explain such a hybrid character for the studied deposit it is proposed that both the shear zone and the granodiorite intrusion contributed significantly to the genesis of the Cumaru gold deposit. Interaction between tectonic and magmatic processes during generation of ore deposits was proposed by Mason (1992) who suggested the existence of a complete series between lode type (structural control only) and porphyry type (magmatic control only).

According to the proposed model, the Cumaru gold deposit would be a intermediary member in this type of continuum, exhibiting both structural and magmatic controls (Fig. 18a). Metamorphic-derived aquo-carbonic fluids were produced when the Serra Ruim shear zone affected the southern flank of the Gradaus greenstone belt sequence. The shear zone was the main conduit for circulation of the aquo-carbonic fluid which probably scavenged gold from the deeper greenstone belt volcanic rocks, precipitating the metal in quartz veins together with a reduced mineral assemblage (sulfides + gold). Intrusion of the granodiorite led to superimposition of a magma-generated brine which mixed with the metamorphic-sourced aquo-carbonic fluid, leading to destabilization of the auriferous complexes and hence triggering gold deposition in a more oxidized assemblage (sulfides + oxides + gold). Such a hybrid model is referred to here as a "lode-porphyry" model (Fig.1Sb). Intermediary deposits between lode and porphyry types have already been recognized in Phanerozoic mesothermal gold deposits (Murray 1986, Sang \& Ho 1987, Morrison 1988), but Cumaru appears to be the first case recorded in Archean terrains.

Porphyry-style gold mineralization, though more typical in Mesozoic-Cenozoic deposits, is consistent with the petrological characteristics and tectonic environment of the Cumaru Granodiorite which is defined as an I-type calc-alkaline pluton of volcanic arc affiliation, similar to Phanerozoic porphyry systems (Wilson \& Kyser 1988; Sillitoe 1989, 1991). Although Archean tectonic regimes-are still extensively debated, plate tectonic models have been applied recently to the Archean by a number of authors (e.g. Cassidy et al. 1989, Sutcliffe et al 1993), and Archean porphyry deposits have been identified by other workers (e.g. Barley 1982, Fraser 1993).

The metallogenic model proposed here for the Cumaru deposit is a new type of gold deposit for the Amazon Craton and it provides a new insight concerning the role of granitoids in mesothermal lode gold genesis in the region. The granitoids appear to have played a very active role in the genesis of these deposits, suggesting a magmatic control that could have been at least as important as the structural control. Deposits of the Cumaru type may occur not only in the Carajás Province but in many other Archean greenstone belt terrains in Brazil. Particularly favourable targets for exploration are the contacts between the greenstone belts and the granite-gneiss terrains, where lithological discontinuities were sites of enhanced shearing and granitoid intrusive activities.

Acknowledgements This research was sponsored by Conselho Nacional de Desenvolvimento Científico e Tecnológico (CNPq, Brazil) grant and $\mathrm{CNPq} \mathrm{PhD}$ scholarship to $\mathrm{M}$. D. Santos. Field work support and drill hole samples were supplied by Mineração Gradaús. The geochemical and fluid inclusions studies were carried out at the Universidade de Brasília, Brazil, and the University of Southampton, UK, under the supervision of Prof. Geraldo B. Santos (Brazil) and Drs. Ian Croudace and Stephen Roberts (UK) respectively. The isotope analyses were performed at the Scottish Universities Research and Reactor Centre, Glasgow, UK. To all these people and institutions the authors are very grateful. 


\section{References}

Althoff, A.M.R.; Villas, R.N.; Giuliani, G. 1994. A mineralização cuprífera da área Bahia, Serra dos Carajás (PA): evolução dos fluidos hidrotermais e modelo metalogenético. Geochim. Brasil., 8:135-155.

Barker, F. \& Arth, J J. 1976. Generation of trondhjemitic-tonalitic liquidus and Archean bimodal trodhjemite-basalt suites. Geology, 4:596-600.

Barley, M.E. 1982. Porphyry-style mineralization associated with early Archean calc-alkaline igneous activity, eastern Pilhara, western Australia. Econ. Geol., 77:1230-1236.

Brown, P.E. \& Lamb, W.M. 1989. P-V-T properties of fluids in the system $\mathrm{HjO} \pm \mathrm{CC}>2 \pm \mathrm{NaCl}$ : new graphical presentations and implications for fluid inclusion studies. Geochim. Cosmochim. Acta, 53:1209-1221.

Cassidy, K.F.; Barley, M.E.; Groves, D.I.; Perring, C.S. 1989. Petrogenesis of Archaean granitoids of the Norseman- Wiluna belt, Western Australia: Indicators of a plate tectonic setting

a 2.7 Ga gold-rich greenstone belt In: HAAPALA, I. \& KÂHKÕNEN, Y. (eds) Precambrian Granitoids Symposium, 1989. Abstracts.. IGCP projects 217 / 247. Geological Survey of Finland, Special paper 8, p. 22-23

Cathelineau, M. 1988. Cation site occupancy in chlorites and illites as a function of temperature. Clay Minerals, 23:471-485

Colvine, A.C.; Fyon, J. A.; Heather, K.B.; Marmont, S.; Smith, P.M.; Troop, D.G. 1988. Archean lode gold deposits in Ontario. Ontario, Geological Survey, (Micellaneous Paper 139), $136 \mathrm{p}$.

Costa, J.B.S.; Araújo, O.J.B.; Santos, A.; João, X.S.J.; Macambira, M.J.B.; Lafon, J.M. 1995. A Província Mineral de Carajás: Aspectos tectono-estruturais, estratigráficos e geocronológicos. Boi. Para. Emílio Goeldi, Série Ciências da Terra, 7:199-235.

DOCEGEO 1988. Revisão Litoestratigráfica da Província Mineral de Carajás. In: Congresso Brasileiro de Geologia, 35, Belém, 1988. Anexo aos Anais... Belém, SBG/NO, p. 1-54.

Faraco, M.T.L.; Carvalho, J.M.A.; Klein, E.L. 1996. Carta metalogenética da Província de Carajá - SE do Estado do Pará, Folha Araguaia (SB-22). Nota Explicativa. Belém, CPRM, 28p.

Field, C. W. \& Fifarek, R.H. 1985. Light stable isotope systematics in the epithermal environment. In: BERGER, B.R. \& BETHKE, P.M. (eds). Geology and geochemistry of epithermal systems. El Paso, Texas, Society of Economic Geologists, p. 99-128 (Reviews in Economic Geology, 2).

Fraser, R.J. 1993. The Lac Troilus gold-copper deposit, Northwestern Quebec: A possible Archean porphyry system. Econ. Geol. 88:1685-1699.

Golding, S.D. \& Wilson, A.F. 1987. Oxygen and hydrogen isotope relations in Archean gold deposits of the Eastern Goldfields Province, Western Australia: constraints on the source of Archean gold-bearing fluids. In: Ho, S.E. \& Groves, D.I. (eds). Recent advances in understading Precambrian gold deposits. Geology Department and University Extension, Univ. West. Australia, p. 703-713 (Publ. II)

Ho, S.E.; Groves, D.I.; Phillips, G.N. 1985. Fluid inclusions as indicators of the nature and source of ore fluids and ore depositional conditions for Archean gold deposits of Yilgam Block, Western Australia. Trans. Geol. Soc. S. Air., 88:149-158.

Hoffman, J. \& Hower, J. 1979. Clay mineral assemblages as low grade metamorphic geothermometers: application to the thrust faulted disturbed belt of Montana, U.S.A. In: Schole, P.A. \& Schluger, P.R. (eds). Aspects of diagenesis. Soc. Econ. Paleont Mineral. p. 55-79 (Spec. Publ. 26).

Huhn, S.R.B. 1992. Geologia, Controle Estrutural e Gênese do Depósito Aurífero Babaçu, Região de Rio Maria, Sul do Pará. Dissertação de Mestrado. Brasília, Universidade de Brasília, $169 \mathrm{p}$.

Huston, D.L. \& Large, R.R. 1989. A chemical model for the concentration of gold in volcanogenic massive sulphide deposits. Ore Geol. Rev., 4:171-200.

Kerrich, R. 1989. Geochemical evidence on the source of fluids and solutes for shear zone hosted mesothermal Au deposits. In BURSNALL, J.T. (ed). Mineralization and Shear Zones. Montreal, Geol. Assoc. Canada, p. 129-197 (Short Course Notes, 6).

Kyser, T.K. 1986. Stable isotope variations in the mantle, In: Valley, J.W.; Taylor, H.P. Jr.; O'Neil, J.R. (eds). Stable isotopes hi high temperature geological processes. Washington, Mineralogical Society of America, p. 141-164 (Reviews in Mineralogy, 16).

Lafon, J.M. \& Macambira, J.B. 1990. Age archéen de la granodiorite Cumaru (Serra dos Gradaús, Pará, Brésil). C. R. Acad. Sei. Paris, 310:1653-1641.

Lafon, J.M. \& Scheller, T. 1994. Geocronologia $\mathrm{Pb} / \mathrm{Pb}$ em zircâo do Granodiorito Cumaru, Serra dos Gradaús, PA. In: Simpósio de Geologia da Amazônia, 4, Belém, 1994. Boletim de Resumos... Belém, SBG/NO, p.321-323.

Leonardos, O.H.; Santos, M.D.; Giuliani, G.; Araújo, L.R. 1991. The Cumaru mesotherma granodiorite-hosted gold mineralization, Amazon Craton, Brazil. In: Ladeira, E.A. (ed.) Brazil gold' 91 , the economics geology geochemistry and genesis of gold deposits. Belo Horizonte, 1991. Proceedings... Rotterdam, Balkema, p. 557-562.

Lindenmayer, Z.G. 1990. Salobo Sequence, Carajás, Brazil: Geology, Geochemistry and metamorphism. PhD thesis. University of Western Ontario, Canada, 406p.

Macambira, J.B.; Kotschoubey, B.; Santos, M.D.; Moura, C.A.V.; Ramos, J.F.F. 1986 Estratigrafia e mineralizações primárias de ouro da aba sul do sinclinório de Gradaús - sul do Pará. In: Congresso Brasileiro de Geologia, 34, Goiânia, 1986. Anais... Goiânia, SBG, v. 5 , p. $1956-1968$.

Macambira, M.J.B. \& Lancelot, J. 1991. Em busca do embasamento arqueano da região de Rio Maria, Sudeste do Estado do Pará. In: Simpósio de Geologia da amazônia, 3, Belém, 1991. Anais... Belém, SBG/NO, p. 49-58.

Mason, R. 1992. Felsic magmatism and hydrothermal gold deposits: A tectonic perspective. In: Bartholomew, M.J.; Hyndman, D.W.; Wogk, D.W.; Mason, R. (ed). Basement Tectonics 8: Characterization and Comparison of Ancient and Mesozoic Continental Margins. International Conference on Basement Tectonics, 8th, Butte, Montana, 1988. Proceedings, Dordrecht, The Netherlands, Kluwer Academic Publishers, p. 679-687.

Matsuhisa, Y.; Goldsmith, J.R.; Clayton, R.N. 1979. Oxygen isotope fractionation in the system quartz-albite-anorthite-water. Geochim. Cosmochim. Acta, 42:1131-1140.

Medeiros, H. 1987. Petrologia da porção leste do batólito granodiorítico Rio Maria, sudeste do Pará. Dissertação de Mestrado. Belém, Centro de Geociências, UFPa, 184p.

Nascimento, J.S. \& Biagini, D.O. 1988. Conhecimento atual da jazida de ouro de Lagoa Seca, sul do Pará. In: Cong. Bras. Geol., 35, Belém, 1988. Anexo aos Anais... Belém, SBG, p. $143-155$
Nesbitt, B.E. \& Muehlenbachs, K. 1989. Geology, geochemistry, and genesis of mesothermal lode gold deposits of the Canadian Cordillera: evidence for ore formation from evolved meteoric water. In: Keays, R.R.; Ramsay, W.R.H.; Groves, D.I. (ed.) The geology of gold deposits: the perspective in 1988.New Haven, The Economic Geology Publishing Co., p.552-563 (Econ. Geol., Monog. 6).

Nitsch, K.H. 1970. Experimental determination of the upper stability of stilpnomelane. Fortschr. Mineral, 47:48-49.

Ohmoto, H. 1986. Stable isotope geochemistry of ore deposits. In: Valley, J.W.; Taylor, H.P. Jr.; O'Neil, J.R. (eds). Stable isotopes in high temperature geological processes. Washington, Mineralogical Society of America, p. 491-559 (Reviews in Mineralogy, 16).

Ohmoto, H. \& Kerrich, D. 1977. Devolatization equilibria in graphitic systems. Am. J. Sci., 277:1013-1044.

Oliveira, C.G. \& Leonardos, O.H. 1990. Gold mineralization in the Diadema shear belt, Northern Brazil. Econ. Geol., 85:1034-1043.

Parry, W.T. 1986. Estimation of XCCh, P, and fluid inclusion volume from fluid inclusion temperature measurements in the system NaCl-CO2-H2O. Econ. Geol., 81:1009-1013.

Pearce, J.A.; Harris, N.B.W.; Tindle, A.G. 1984. Trace element discrimination diagrams for the tectonic interpretation of granitic rocks. J. Petrol., 25:956-983.

Phillips, G.N. \& Groves, D.I. 1983. The nature of Archaean-gold-bearing flluids as deduced from gold deposits of Western Australia. J. Geol. Soc. Australia, 30:25-39.

Pitcher, W.S. 1983. Granite type and tectonic environment. In: Hsu, K.J. (ed.) Mountain building process. New York, Academic Press, p. 19-40.

Ramboz, C.; Pichavant, M.; Weisbrod, A. 1982. Fluid immiscibility in natural process II: use and misuse of fluid inclusion data. Chem. Geol., 37:29-48.

Roedder, E. 1984. Fluid Inclusions. Washington, Mineralogical Society of America, 646 p. (Reviews in Mineralogy, 12)

Romberger, S.B. 1988. Geochemistry of gold in hydrothermal deposits. U.S. Geological Survey Bulletin 1857, A9-A25.

Romberger, S.B. 1990. Transport and deposition of gold in hydrothermal systems. In: Robert, F Shearan, P.A.; Green, S.B. (eds). Greenstone gold and crustal evolution. NUNA Conference Volume, Val d'Or, 1990. Proceedings..., Montreal, Geol. Assoc. Canada, p. 61-66.

Ryzhenko, B.N. \& Volkov, V.P. 1971. Fugacity coefficient of some gases in a broad range of temperatures and pressures. Geochim. Internal., 8:468-481.

Santos, M.D. 1995. O papel dos granitóides na gênese dos depósitos de ouro tipo Iode arqueano : Caso da jazida do Cumaru-PA. Universidade de Brasília, tese de doutorado, $157 \mathrm{p}$.

Santos, M.D. \& Leonardos, O.H. 1995. Sistema de fluidos e modelo genético do depósito aurífero do Cumaru, SE do Estado do Pará. Boi. Para. Emílio Goeldi, Série Ciências da Terra, 7:237-262.

Saueressig, R. 1988. Depósito de Cobre e Zinco do Corpo Quatro, Pojuca. In: Congresso Brasileiro de Geologia, 35, Belém, 1988. Anexo aos anais... Belém, SBG., p.l 15-119.

Seward, T.M. 1989. The hydrothermal chemistry of gold and its implications for ore formation: Boiling and conductive cooling as exemples. In: Keays, R.R.; Ramsay, W.R.H.; Groves, D.I. (eds). The Geology of Gold Deposits: Perspective in 1988. New Haven, The Economic Geology Publishing Co. p. 398-404 (Econ. Geol. Monog. 6).

Seward, T.M. 1984. The transport and deposition of gold in hydrothermal system. In: Foster, R.P. (ed). Gold' 82: The geology, geochemistry and genesis of gold deposits, Zimbabwe, 1982 Proceedings... Rotterdam, Balkema, Geol. Soc. Zimbabwe, p .165-181 (Spec. Publ. 1).

Schobbenhaus, C.; Campos, D.; Derze, G.R.; Asmus, H.E. 1981. Mapa geológico do Brasil e da área oceânica adjacente, incluindo os depósitos minerais. Brasília, Ministério das Minas e Energia/DNPM.

Sillitoe, R.H. 1989. Gold deposits in western Pacific islands arcs: The magmatic connection. In: Keays, R.R.; Ramsay, W.R.H.; Groves, D.I. (eds). The Geology of Gold Deposits: Perspective in 1988. New Haven, The Economic Geology Publishing Co., p. 274-291 (Econ. Geol., Monog. 6).

Sillitoe, R.H. 1991. Intrusion related gold deposits In: Foster, R.P. (ed). Gold Metallogeny and Exploration. Glasgow, Blackie and Son Ltd., p. 165-209.

Smith, T.J.; Clocke, P.L.; Kesler, S.E. 1984. Geochemistry of fluid inclusions from the Mclntyre-Hollinger gold deposit, Timmins, Ontario, Canada. Econ. Geol, 79:1265-1285.

Sutcliffe, R.H.; Barrie, C.T.; Burrows, D.R.; Beakhouse, G.P. 1993. Plutonism in the Southern Abitibi Subprovince: A Tectonic and Petrogenetic Framework. Econ. Geol, $88: 1359-1375$

Taylor, H.P. Jr. 1974. The application oxygen and hydrogen isotope studies to problems of hydrothermal alteration and ore deposition. Econ. Geol., 69:843-883.

Taylor, B.E. 1986. Magmatic Volatiles: Isotopic variation of C, H and S. In: Valley, J.W.; Taylor, H.P. JR.; O'Neil, J.R. (eds). Stable isotopes in high temperature geological processes. Washington, Mineralogical Society of America, p. 185-225 (Reviews in Mineralogy, 16).

Vanko, D.A.; Bodnar, R.J. Sterner, S.M. 1988. Synthetic fluid inclusions: VIII. Vapor-saturated halite solubility in part of the system $\mathrm{NaCl}-\mathrm{CaCk}-\mathrm{HjO}$, with application to fluid inclusions from oceanic hydrothermal systems. Geochim. Cosmochim. Acta 52:2451-2456.

Weisbrod, A. 1981. Fluid inclusions in shallow intrusives. In: Hollister, L.S. \& Crawford, M.L. (ed). Fluid Inclusions: Applications to Petrology. Calgary, Mineral. Assoc. Canada, short course handbook, v. 6, p. 241-271.

William-Jones, A.E. \& Samson, I. A. 1990. Theoretical estimation of halite solubility in the system $\mathrm{NaCl}-\mathrm{CaCb}-\mathrm{HaO}$ : applications to fluid inclusions. Canadian Mineral., 28:299-304.

Wilson, J.W.J.; Kesler, S.E.; Cloke, P.L.; Kelly, W.C. 1980. Fluid inclusion geochemistry of the Granisle and Bell porphyry copper deposits, British Columbia. Econ. Geol., 75:45-61.

Wilson, M.R. \& Kyser, T.K. 1988. Geochemistry of porphyry-hosted Au-Ag deposits in the Little Rock Moutains, Montana. Econ. Geol., 83 :1329-1346.

Manuscrito A-959 Recebido em 26 de fevereiro de 1998 Revisão dos autores em 18 de maio de 1998 Revisão aceita em 22 de maio de 1998 